Review

\title{
The Impacts of Climate Change Mitigation Strategies on Animal Welfare
}

\author{
Sara Shields * and Geoffrey Orme-Evans \\ Humane Society International, 2100 L Street NW, Washington, DC 20037, USA; \\ E-Mail: gevans@hsi.org \\ * Author to whom correspondence should be addressed; E-Mail: sshields@hsi.org; \\ Tel.: +1-202-676-2368; Fax: +1-202-778-6132.
}

Academic Editor: Clive Phillips

Received: 30 January 2015 / Accepted: 27 April 2015 / Published: 21 May 2015

Simple Summary: Climate change is probably the most important environmental issue of our time. Raising animals for food contributes to the production of greenhouse gases implicated in the global warming that is causing climate change. To combat this ecological disaster, a number of mitigation strategies involving changes to agricultural practices have been proposed. However, some of these changes will impact the welfare of farmed animals. This paper reviews selected climate change mitigation strategies and explains how different approaches could have negative or positive effects.

\begin{abstract}
The objective of this review is to point out that the global dialog on reducing greenhouse gas emissions in animal agriculture has, thus far, not adequately considered animal welfare in proposed climate change mitigation strategies. Many suggested approaches for reducing emissions, most of which could generally be described as calls for the intensification of production, can have substantial effects on the animals. Given the growing world-wide awareness and concern for animal welfare, many of these approaches are not socially sustainable. This review identifies the main emission abatement strategies in the climate change literature that would negatively affect animal welfare and details the associated problems. Alternative strategies are also identified as possible solutions for animal welfare and climate change, and it is suggested that more attention be focused on these types of options when allocating resources, researching mitigation strategies, and making policy decisions on reducing emissions from animal agriculture.
\end{abstract}


Keywords: animal welfare; climate change; mitigation strategies

\section{Introduction}

Climate change is arguably the most important environmental issue of our time. With severe and widespread destructive effects, warming of the planet threatens ecological systems, peoples' livelihoods, and species survival [1]. Animal agriculture is an important source of greenhouse gas (GHG) emissions and has been implicated as a serious contributor to climate change [2]. To reduce the contribution of emissions attributable to animal agriculture, a number of mitigation strategies involving changes to farming practices have been proposed. Although this is an important and timely goal, and many of the proposed solutions seem reasonable on the surface, mitigation strategies can have complex effects on people and animals in practice. While there has been occasional mention [3], in the global discussion on climate change there has generally been a dearth of attention paid to the animal welfare impacts of the proposed abatement options [4,5], and some of the suggested livestock management approaches would have severe and wide-ranging impacts on the animals.

At the same time, in other arenas there is a growing international social movement afoot aimed at addressing animal welfare, the physical and psychological state of animals [6]. There are many animal welfare issues associated with commercial farming practices, especially in industrial agricultural production systems, where animals are often confined indoors at high stocking densities. The conditions in which the animals are kept are a matter of serious deliberation in legislative, corporate, investment and trade organizations, among many others around the world. Overarching calls to increase animal productivity, by, for example, pushing animals (either genetically through selective breeding, with hormone drugs, or through feed changes) to produce more milk or meat, or to produce more offspring faster, can also be considered in light of potential health and welfare consequences.

This paper argues that the potential impact of climate change mitigation strategies on animal welfare should be acknowledged and considered in the ongoing debate and discussion centered on climate change approaches and climate change research, with the aim of maximizing co-benefits of sustainability while avoiding negative tradeoffs. Specific mitigation strategies are discussed and their potential impacts on the animals are assessed. As examples of alternative pathways forward, some mitigation approaches that have no effect on animal welfare or even a positive effect are also reviewed. Given the scope and severity of the impacts on animals, and the increasing global support for more welfare-friendly practices, animal welfare concerns should become a more prominent part of the dialog and policy decisions on climate change mitigation practices in animal agriculture.

\section{Background on Climate Change and Mitigation Strategies}

The Earth's surface has been successively warmer over each of the last three decades compared to any preceding decade since 1850 [7]. Human activities are responsible (with a 95\%-100\% probability) for the recent global warming and the marked increase in global atmospheric concentrations of carbon dioxide $\left(\mathrm{CO}_{2}\right)$, methane $\left(\mathrm{CH}_{4}\right)$ and nitrous oxide $\left(\mathrm{N}_{2} \mathrm{O}\right)$ to above pre-industrial values [8]. By sector, greenhouse gas pollution originates primarily from industry; agriculture, forestry and other land use 
(AFOLU); buildings; and transport [9]. Separated out, animal agriculture emits a significant portion, estimated from $7 \%$ to $18 \%$ of anthropogenic greenhouse gas emissions [10].

Livestock contribute both directly and indirectly to climate change. Enteric fermentation and manure associated emissions are direct, while production and transport of feed (including the fossil fuels used in manufacturing chemical fertilizers) and land use changes (such as conversion of forest to pasture and crop land) contribute indirectly [10]. About $44 \%$ of the emissions generated by livestock are $\mathrm{CH}_{4}$, which is released during enteric fermentation (eructation in ruminants) and emitted from manure decomposition; $27 \%$ are in the form of $\mathrm{CO}_{2}$ emitted during the production and transport of animal products and feed, and $29 \%$ are $\mathrm{N}_{2} \mathrm{O}$ attributable to manure and fertilizer [2]. There is a clear need to address the contribution that farming animals makes to global warming.

To combat climate change caused by animal agriculture, a number of mitigation strategies have been proposed, as well as policy options to implement such strategies [11]. A theme that runs through this literature is greater efficiency of production, with the aim to achieve more output for a given level of resources used. As explained in the pivotal 2006 United Nations, Food and Agriculture (FAO) report, Livestock's Long Shadow:

The most promising approach for reducing methane emissions from livestock is by improving the productivity and efficiency of livestock production, through better nutrition and genetics. Greater efficiency means that a larger portion of the energy in the animals' feed is directed toward the creation of useful products (milk, meat, draught power), so that methane emissions per unit product are reduced. The trend towards high performing animals and towards monogastrics and poultry in particular, are valuable in this context as they reduce methane per unit of product. The increase in production efficiency also leads to a reduction in the size of the herd required to produce a given level of product. Because many developing countries are striving to increase production from ruminant animals (primarily milk and meat), improvements in production efficiency are urgently needed for these goals to be realized without increasing herd sizes and corresponding methane emissions [12] (pp. 119-120)

However, by far, the most substantial emissions reductions can come through adaptations in current systems rather than requiring a shift to industrialized systems [2]. This is important from an animal welfare perspective. While there can be negative animal welfare impacts in all production systems, industrialized production has inherently problematic effects on billions of animals globally. Thus, it is important that there is significant alignment in both animal welfare and climate goals. Some ways in which they are less compatible are discussed in Section 2.

\section{Mitigation Strategies and Possible Negative Animal Welfare Effects}

\subsection{Feed Changes}

Given that feed production accounts for about $47 \%$ of livestock emissions [2] (p. 18), it is a key target for mitigation. However, there are a number of welfare concerns with some of the current proposals to reduce emissions using feed alterations. 


\subsubsection{Grain Finishing Feedlot Cattle}

One strategy for mitigating methane emissions with feed changes is by including more concentrates in addition to, or in place of, a proportion of dietary forage. Although emissions per animal may rise as productivity improves, there is generally a reduction in the greenhouse gases released on a per $\mathrm{kg}$-product produced basis [10,13]. In intensive production systems, grain feeding of livestock often entails removing cattle raised for beef from pastures to provide the finishing ration in a feedlot. This is a common system in the United States and is being emulated in other parts of the world, such as Latin America. In Brazil, the practice of finishing cattle in feedlots increased 50\% (from two to three million animals) from 2003 to 2010 [14].

The digestive system of cattle is best adapted to roughage provided by grass-based diets [15], and the natural behavior of cattle is to graze throughout the day. However, the typical routine in feedlots is to gradually reduce the proportion of forage in the ration over time, eventually reaching diets that can be as high as $90 \%$ grain [16]. In enlarging Brazilian feedlots, the expected trend is a decrease in the amount of roughage in feedlot diets, with an already observed reduction from $29 \%$ in 2009 to $21 \%$ in 2011 [17].

In cattle feeding systems with high ratios of concentrate to forages, digestive problems are common. The starches in this concentrated diet are quickly digested and fermentation acids can build up disrupting the normal function of the rumen [16]. Abnormal rumen function and digestive disorders can lead to acidosis, bloat, and if persistent, liver abscesses, and even the foot disorder laminitis $[15,18,19]$. Maintaining normal rumen function on these diets is a constant challenge for the feedlot industry; one quarter of cattle mortality in feedlots can be attributed to digestive disorders [20].

For both acidosis and bloat, increasing the amount of forage in the diet can stimulate chewing and promote saliva production, which have a buffering effect, and thus reduce the likelihood of a sinking $\mathrm{pH}$ level and destabilization of the microbial population in the rumen [16,21].

Finishing calves in a feedlot usually involves transporting them from their natal pastures. In the United States, nearly two-thirds (63\%) of cattle and calves raised for beef are sold through an auction barn after leaving the farm [22], thus, many calves are moved twice before arrival at a feedlot.

Transport takes a physical and psychological toll on animals. Stressors include unfamiliar surroundings, novelty, noise, vibration, social regrouping, loading and unloading, and feed and water deprivation [23-25], although many factors, such as preconditioning [26] and location in the vehicle during the journey [27] can alter the effect. The stress of transport can lead to immunosuppression and an increase in disease susceptibility, including the ubiquitous Bovine Respiratory Disease (RBD) problem $[25,28,29]$.

\subsubsection{Concentrated Diets for Pigs}

In cases where intensification of animal agriculture is accompanied by better access to resources, then there may be benefits for welfare in terms of providing more nutritionally complete rations. However, pigs are also often fed highly concentrated grain-based diets in intensive production. Concentrated diets may be fed to pigs in a finely ground or pelleted ration and are expected to reduce GHG emissions due to their high digestibility. For example, in a case study of intensive pig production in East and South East Asia, the FAO explored changes to swine diets as a potential mitigation strategy, including increased 
digestibility of feed. In intermediate (not fully industrialized) systems, by changing the feed along with other management changes, emissions could be reduced by $32 \%$ to $38 \%$ [2].

Pigs' stomachs are biologically designed for numerous, small meals throughout the day of high fiber feedstuffs [30]. However, in intensive production, they have little access to roughage. Feed processing improves feed-to-gain efficiency, but it is also associated with intestinal problems. These low fiber diets can impact mucosa integrity leaving pigs prone to gastric ulcers in the pars esophageal region of the stomach [31]. This is a problem worldwide. Reports vary, with incidence of pigs showing distinct signs of ulceration between farming operations ranging from zero to nearly $90 \%$ [32-36]. For pigs in the growing/finishing stages of production, ulceration is a common cause of mortality [37]. The production systems in which most pigs are kept appear to have a large impact on the incidence of these ulcers, as pigs with access to straw, sawdust, or outdoor paddocks have fewer ulcers than those confined on bare, solid or slatted concrete floors [32,38,39].

\subsubsection{Feed Additives}

Feed additives can be used to inhibit $\mathrm{CH}_{4}$ production in a variety of species. However, some dietary additives that are being tested have potential animal health concerns. For example, in vitro studies have shown that fumarate can work as an alternative to $\mathrm{CH}_{4}$ as a sink for $\mathrm{H}_{2}$ in the rumen, but feeding fumarate in its free acid form can lower rumen $\mathrm{pH}$ and inhibit fiber digestion, while feeding it in salt form can induce toxicity. Effective doses may well exceed current dietary recommendations [40]. Especially in low protein diets, nitrates are also potential $\mathrm{CH}_{4}$ mitigation agents. However, the intermediate product from nitrate metabolism, nitrite, is toxic, and so feeding it requires a gradual acclimation to a high dietary intake in order to avoid nitrite toxicity [10,41]. Another proposed supplement, sulfate, has been linked to sulphur-induced polioencephalomalacia, a condition in US feedlot cattle associated with excessive production of $\mathrm{H}_{2} \mathrm{~S}$ in the rumen from diets high in distillers grains-co-products from the ethanol industry, which are high in sulfate [10,42]. The FAO cautions that more research is needed [10]. Mitigation strategies should steer clear of feeding substances that might endanger the animals, either outright or in the absence of highly skilled management.

\subsection{Genetic Selection}

In general, as animals become more productive, greater feed intake is needed to support the energy requirements associated with growth or lactation, but the proportion of total energy requirements required for maintenance decreases [43]. Thus the feed input per unit of product produced is reduced. Further, with increases in productivity, fewer animals are needed to reach a given level of output [43]. In the climate change mitigation literature, this concept is often exemplified with dairy cows. For example, in 1944, the diverse breeds comprising the US dairy cow population produced an annual milk yield of $2074 \mathrm{~kg}$ per cow, but by 2007 the genetic pool had shrunk, and Holsteins were the dominant breed, while milk production more than quadrupled to $9193 \mathrm{~kg}$ per cow. In 1944 there were 25.6 million dairy cows in the United States with an annual production of 53.0 billion kg of milk, while in 2007 the total US dairy herd had declined to 9.2 million cows, but they produced 84.2 billion $\mathrm{kg}$ of milk. Because of this per cow increase in production, the total carbon footprint for the US dairy industry in 1944 was 194 million tons of $\mathrm{CO}_{2}$-equivalent $\left(\mathrm{CO}_{2}\right.$-eq.), while in 2007 the industry's carbon footprint was only 114 million 
tons [44]. Much of this individual increase in productivity can be attributed to genetic selection, although dietary changes also contributed.

Swine and poultry produce relatively small amounts of enteric $\mathrm{CH}_{4}$, but their manure can be a significant source of GHG production. Therefore, maintaining or improving feed conversion efficiency in these species, and subsequently reducing the volume of manure produced for a given level of output, is considered a major strategy for mitigating $\mathrm{CH}_{4}$ and $\mathrm{N}_{2} \mathrm{O}$ [45]. However, there is evidence across species that overemphasis on productivity in genetic selection can lead to unintended negative effects on animal welfare.

\subsubsection{Effects of Breeding for Yield on Dairy Cow Welfare}

While selective breeding has been successful in producing cows that yield more milk with less feed, this change is not without costs. Detrimental, unintended side-effects on the health of dairy cows have accompanied the physiological demands of greater productivity [46].

Following the birth of her calf, a dairy cow enters a state of negative energy balance. Genetic selection for increased milk yield increases feed intake, but high yielding cows can experience greater negative energy balance [47] than cows producing less, so they are vulnerable to health problems. There is a strong correlation between maximum metabolic load and laminitis [48], lameness and ketosis [49,50]. Failure to meet the nutritional demands of highly productive dairy cows can also lead to an array of additional metabolic diseases including fatty liver disease, ketosis and periparturient hypocalcemic paresis (milk fever) [51].

Mastitis, a bacterial infection of the udder, is the most commonly reported health problem in the US dairy industry, affecting $16.5 \%$ of cows [52]. The udder and teats of mastitic cows are sensitive to the touch, and in severe cases, clinical signs include swelling and pain sometimes accompanied by fever and depression. It is one of the leading reasons for culling of cows [52]. Although there are many risk factors for mastitis, such as lack of cleanliness in cow housing areas, research has consistently shown an association between mastitis and the amount of milk produced. For example, a study of over 3000 cows in 85 trials in eight different countries found that even with similar management conditions, higher yielding cows contracted more mastitis than lower yielding cows [53]. Many studies have reported that milk yield and mastitis are genetically correlated [54-59].

Further, high genetic merit dairy cows require high energy feeds to meet the substantial energy demands of early lactation. They often receive a high proportion of cereal grains, and one model found that cows selected for greater milk fat and protein fed a 50\% grain diet had lower emissions ( $1.05 \mathrm{~kg} \mathrm{CO}_{2}$-eq. per kilogram of energy-corrected milk), than cows with a $25 \%$ grain diet and summer grazing (1.19 kg per kilogram of energy-corrected milk) [60]. However, dairy cows are prone to digestive disorders such as sub-acute ruminal acidosis (SARA) [61,62]. Diets that are rich in grains alter rumen metabolic balance and can induce an explosive proliferation of Streptococcus bovis and Lactobacillus bacteria species. [63]. The resulting rumen acidosis eventually leads to erosion and ulceration of the ruminal epithelium and chronic symptoms including lethargy, reduced feed intake, diarrhea, and discomfort among others. 


\subsubsection{Effects of Breeding for Productivity on Swine Welfare}

Increases in the productivity of swine, largely achieved through genetic selection, have been cited as climate change mitigation progress [10] (p. 100-101). For example, a 2013 FAO report cited data provided by the US National Pork Board. Between 1959 and 2009, there was a 29\% increase in the number of hogs marketed in the United States, yet the size of the breeding herd has been reduced by 39\%. This is due in part to the steady increase in litter size from 7.10 in 1974 to 9.97 piglets in 2011 and the concomitant change in the amount of pork produced from a single breeding animal from 775 to $1828 \mathrm{~kg}$. Feed efficiency also increased by $33 \%$. This has reduced the carbon footprint per $454 \mathrm{~kg}$ of hot dressed carcass weight produced by $35 \%$ [10,45]. However, the original source for this calculation [64] does not appear to be peer-reviewed, and total emissions in the US pork industry have increased overall with greater pork production. Despite this, the suggestion is that the type of throughput achieved in the United States, if adopted more widely in the developing world, could be an approach to climate change mitigation. However, some of the key unintended animal welfare consequences that may accompany such a change include low piglet viability and severe feed deprivation of breeding sows in order to prevent them from becoming obese.

Selectively breeding for increased litter size reduces the proportion of surviving piglets $[65,66]$. Herpin et al. (1993) postulated that genetic changes have altered body fat metabolism, body composition, and hormonal state, resulting in lean tissue growth that makes piglets heavier but less mature at birth compared to lines that have not been so intensely selected for production traits. This reduces piglet survival rate [67], which is an intractable problem in the pork industry. Selection for leanness may have also inadvertently decreased the nutritional quality of sows' milk [68], in turn further affecting survival of the piglets.

Selectively bred for productivity, growing/finishing pigs in the United States are fed to satiety to meet their full genetic potential, but breeding animals must often be feed restricted to prevent excessive weight gain and fat deposition. Confined sows are typically fed just half the amount they would choose to consume if fed ad libitum. This leads to a chronic hunger problem including persistent, unfulfilled feeding motivation [69-71]. Short feeding times and lack of an outlet for natural foraging behavior are underlying causes of abnormal stereotypic behavior, discussed below in Section 2.4.1.

\subsubsection{Effects of Breeding for Productivity on the Welfare of Chickens}

As with swine, genetically linked productivity improvements in poultry have also been tied to climate change benefits through feed conversion efficiency [10] and the extremely rapid growth rate of modern broiler chickens (raised for meat). Broilers now grow from hatch to market weight in five weeks or less. Annual growth rates have increased 3.3\% over the past 50 years, and broiler chickens now grow more than four times faster than they did in 1957 [72]. Using a life-cycle assessment model, one study estimated that genetic changes in average U.K. broiler chickens have achieved a $1 \%$ reduction per year in greenhouse gases over the last 20 years [73].

These animals now grow so fast that muscle outpaces bone development, leading to metabolic bone disease. As a result, broiler chickens often suffer from leg deformities and lameness [74-76], including tibial dyschondroplasia, angular bone deformities, spondylolisthesis, epiphyseitis, and in severe cases, 
rupture of the gastrocnemius tendon. Studies are consistent in showing that approximately 26\%-30\% of broiler chickens by 40-42 days of age suffer from gait defects severe enough to impair walking ability [76-78]. Additional research strongly suggests that while conformational differences account for some gait differences [79], birds at this level of lameness are probably in pain [80-82].

Not only do rapidly growing broiler chickens suffer from musculoskeletal diseases, but they are also afflicted by metabolic disorders. Ascites is a condition in which rapidly growing broiler chickens do not have the heart and lung capacity needed to distribute oxygen throughout the body and is a leading cause of mortality as the birds reach market weight [83]. Sudden Death Syndrome (SDS) is associated with acute heart failure caused by dysrhythmias. Young birds die from SDS after sudden convulsions and wing-beating, and are frequently found lying on their backs [84]. The condition has been recognized since the 1950s as more broiler chickens were grown in large numbers for commercial production [76]. Sudden death syndrome (SDS) and ascites together can account for $50 \%$ of the mortality of highly productive broiler chicken strains $[85,86]$.

The parent generation of broiler chickens grown for meat shares the same genetics as their progeny. Like breeding sows, these broiler breeders must be feed restricted, or they will suffer from health and reproductive disorders due to weight gain. Parent birds are usually feed-restricted starting when they are as young as one week old [87]. In many parts of the world broiler breeders may be fed on a "skip-a-day" regimen, in which the animals are fed as infrequently as every other day-though this practice has been outlawed in several European countries [88]. Experimental studies suggest that artificial selection for increased body weight may have altered the brain mechanism controlling satiety and appetite [89], and evidence from behavioral studies suggests that feed restriction interferes with learning [90] and causes stress [91,92], boredom, and chronic hunger [93-95]. Breeding birds receive only 25\%-50\% of the amount of feed they would otherwise eat if given free access [93]. While free-range chickens normally devote about $50 \%$ of their daily time budget to foraging [96,97], feed restricted parent birds can consume their daily feed allotment in as little as $15 \mathrm{~min}$ [87]. Feed restriction is believed to cause undernourishment, nutritional deficiency, and abnormal behavior including increased pecking at non-feed objects, pacing, and heightened aggression [87,98]. Given that target body weights for broiler breeders have changed little in the past 30 years, but broiler body weight continues to increase, the welfare of parent birds may become more serious in the future as they will be feed deprived to an even greater extent [99].

\subsubsection{Genetic Selection with Regard to Welfare}

While genetic selection for productivity can have negative side-effects for animal welfare, this is not necessarily always the case. Although progress may be slow, it is possible to select for both welfare associated traits and productivity simultaneously. For example, while there is an overall negative correlation between walking ability and growth rate of broiler chickens, some individuals do have both good gait scores and high productivity. Given enough time, it might be possible to successfully select for both traits [100]. Where animals can be bred to produce the same amount of meat or milk, but with less feed, GHG emission intensity $\left(\mathrm{CH}_{4} /\right.$ unit animal product) is reduced. The most efficient animals produce less $\mathrm{CH}_{4}$ and $\mathrm{N}_{2} \mathrm{O}$ than the population average [101], and there might not be a further welfare impact if selection focused on these animals. Direct selection on reduced $\mathrm{CH}_{4}$ production could also be 
a possibility. For example, in one study of sheep the heritability of $\mathrm{g} \mathrm{CH}_{4} /$ day was 0.29 with no genetic correlation with live weight, and a slightly economically favorable correlation with fleece weight [102].

\subsubsection{Mismatching Genetics and Environment}

According to the FAO, the single most effective GHG mitigation strategy in many regions of the world is to increase animal productivity [10] (p. 100). Raising imported animals selected for production traits, instead of traditional breeds is part of that strategy. However, the FAO also cautions that while achieving the genetic potential of highly productive breeds is important, these animals should not be imported into environments where climate or management limitations would prevent the animals from achieving this potential. In new regions or countries, animals from genetic lines with high production potential may actually perform worse than native breeds or crossbreeds, especially compared to those well-adapted to local disease and climactic conditions [10] (p. 104). Some regions have seasonal fluctuations in feed quality and nutrient management, and, as high genetic merit breeds have exacting nutritional requirements, they do not always thrive as expected.

In southern India, for example, efforts to replace the native Vechur cow with imported Holsteins have been disappointing, because Holsteins were not bred for performance under the local conditions. While the small Vechur cows produce only one-tenth of the milk hoped for from Holsteins, they are hardy, heat and humidity tolerant and resistant to local diseases and ticks. Under the these environmental conditions in India, Holsteins do not produce the same milk yield that they do in more temperate climates, and the costs of keeping the animals alive and healthy may be greater than any added productivity [103].

In Africa, resistance to trypanosomiasis is a factor that limits the geographical distribution of cattle breeds. Indigenous taurine (humpless) breeds of cattle including the N'Dama and West African Shorthorn are genetically trypanotolerant [104], but European taurine breeds have no resistance, and even Zebu cattle imported from other regions of the continent do not thrive in the humid tropics of West Africa occupied by tsetse flies, vectors of trypanosomiasis [103]. Clearly there are limits to importing more highly productive breeds in this large swath of the world, and such circumstances call in to question the notion of "genetic improvement"-indeed the improved breeds here would appear to be the ones that can best survive the local conditions.

In Brazil, more fertile and adapted breeds, such as the Brazilian Gir, are increasing in popularity [105]. Indigenous breeds are better adapted to local conditions, and more readily able to avoid predators, tolerate heat or other weather extremes, resist parasites and endemic diseases, and scavenge for feed or consume local feed resources. For example, in the subtropical climate zone, with seasonal rainfall patterns that do not permit continuous vegetation growth, Zebu and Sanga cattle are more resistant to ticks and tick-transmitted diseases as well as feed scarcity and seasonal high temperatures [106].

While promoting highly productive genetics to address climate change will reduce GHG emissions in some ways, maintaining biodiversity and the genetic resources of locally adapted breeds will be needed to complement other climate change mitigation strategies and to ensure the animals thrive. A potential solution may be more research and genetic selection of local breeds, but only with due consideration to welfare. Cradle-to-grave analyses that include the full range of trade-offs will become increasingly necessary [107]. Genetic suitability for survival in less hospitable regions with more 
variable climates and diverse, changing feed resources is currently, and may become even more so, an essential requirement for both human and animal welfare.

\subsection{Growth and Yield Promoting Biotechnologies}

Some authors are calling attention to the wide application of growth promoting technologies, including $\beta$-adrenergic agonists ( $\beta$ AAs) and recombinant bovine somatotrophin ( $\mathrm{rbST}$ ), for their climate change mitigation potential $[108,109]$. While the research to date has focused on US production systems, the call is being made in the context of meeting increasing global demand for animal protein. Zilpaterol hydorchloride and ractopamine hydrochloride are $\beta A A$ s that are used as feed additives in grain rations for cattle [110]. $\beta A A$ As are fed in a 20-40 day period prior to slaughter to improve feed efficiency and weight gain [111]. The growth hormone rbST is used in the dairy industry to increase milk yield and feed conversion efficiency [108]. However, both rbST and $\beta$ AAs are cause for substantial animal welfare concern $[110,112,113]$.

\subsection{1. $\beta$-Adrenergic Agonists}

Using Life Cycle Analysis (LCA) modeling, Stackhouse et al. (2012) found that the use of $\beta A A s$, in combination with antibiotics, ionophores, and hormone implants, as is common in US feedlots, decreased the carbon footprint of Angus beef production by 9\% [109], and therefore advocated their use as a potential mitigation option. Cooprider et al. (2011) calculated that feedlot cattle fed ractopamine hydrochloride along with hormone implants and antibiotics had a $31 \%$ decrease in emissions per finished steer given the improved feed efficiency [114]. However, anecdotal reports of changes in behavior and more cattle deaths when $\beta$ AAs were being fed has led researchers to investigate [109]. One recent study found that cattle fed $\beta A A$ s along with a growth implant (trenbolone acetate and estradiol) engaged in more agonistic behavior including bulling and pushing [115]. A large-scale investigation by two major US agricultural universities examined datasets provided by feedlot operators also confirmed the field observations, finding that the cumulative death rate is as much as $90 \%$ greater in animals administered a $\beta \mathrm{AA}$, and that $40 \%-50 \%$ of deaths among groups administered a $\beta \mathrm{AA}$ could be explained by administration of the drug [110]. Imports of animal products containing beta agonists is banned in many countries, including the EU, Russia, and China [116].

The $\beta A A$ ractopamine hydrochloride is also fed to swine, where the side-effects that have been elucidated to date include elevated heart rate, difficulty walking [117], increased aggression [118], abnormal behavior [119], and hoof lesions [120]. Observations at slaughter plants additionally find that difficulty walking due to ractopamine may contribute to a greater incidence of non-ambulatory (or "downed") pigs, those too weak to stand and walk on their own accord [117]. The number of studies investigating the animal welfare effects of $\beta A A s$ is, thus far, small, but given the problems identified already, calls for their increased use clearly should be made more cautiously.

\subsubsection{Recombinant Bovine Somatotrophin}

Also called Bovine Growth Hormone, rbST is a protein hormone that redirects nutrient partitioning during lactation and can increase milk yield by $8 \%-36 \%$ [121]. On a per unit of milk produced basis, 
it has been show that rbST reduces the maintenance energy and protein requirements of cows by $11.8 \%$ and $7.5 \%$, respectively, and total feed requirements by $8.1 \%$ [121]. It also reduces $\mathrm{N}$ excretion on a per liter of milk produced basis. Although overall $\mathrm{N}$ excretion increases in rbST treated cows, because they consume more feed, each cow produces more milk, so estimates calculated on a per liter basis report a reduction in nitrogen excretion between approximately 9\% [108] and 15\% [122]. Per unit of milk, the dilution of maintenance conferred by the use of rbST can result in a reduction in manure production by $6.8 \%$ and $\mathrm{CH}_{4}$ output by $7.3 \%$ [108].

While rbST is banned in the European Union, Canada, Japan, Australia, and New Zealand [10], the drug is approved in the United States, despite substantial controversy. One of the primary welfare concerns associated with the increased milk production caused by rbST is the potential risk for mastitis. Some of the initial studies on rbST indicated that its use was linked to an increase (for example, Burton et al., 1990 [123] and Pell et al., 1992 [124], but see White et al., 1994 [53] for counter examples).

A 1999 report of the Scientific Committee on Animal Health and Animal Welfare (SCAHAW), a working party of independent scientists appointed by the European Commission to assess rbST, reviewed approximately two dozen studies and concluded that rbST usage increases the risk of clinical mastitis and the length of infections [113]. This finding was supported by a review published by the Canadian Veterinary Medical Association (CVMA) [112]. The CVMA performed a series of meta-analyses to combine data from all randomized clinical trials that had been published in peer-reviewed journals or which were provided by Health Canada for the registration of rbST in the country. The CVMA found that rbST increased the risk of clinical mastitis by approximately $25 \%$, closely agreeing with the SCAHAW report. Subsequently, rbST was not approved for use in Canada, due to animal health concerns.

The debate between researchers in different countries largely centers on the question of whether increases in mastitis are due to rbST treatment per se or to the increase in productivity caused by rbST, the same as would be expected when genetic selection leads to greater milk production. White et al. (1994) argue that treatment differences in mastitis are within the range predicted using estimates from genetic studies. And using this logic they conclude that rbST treatment had no effect on mastitis [53]. In contrast, SCAHAW (1999) argue that what matters is the result on the welfare of the animals, which is the same whether it is the drug itself or the increase in productivity that causes the mastitis [113].

In addition to problems with mastitis, there is also concern that rbST treatment may increase the risk of lameness and foot and leg disorders. While many early studies failed to find a detectable difference between rbST treated and control animals [121,125-129], others found a slight increase in the number of cows culled due to lameness [130] and slightly more feet and leg problems [130,131]. As with the early work on mastitis and rbST, in studies with small cow numbers, low statistical power may have prevented detection of effects, and slight increases would be hard to find.

However, both the SCAHAW committee and the CVMA review panel found an increased incidence of foot and leg disorders associated with the long-term administration of rbST [112,113]. The CVMA review panel found that cows treated with rbST were at an estimated 55\% increase in the risk of developing clinical signs of lameness, and this is now reflected on the Posilac drug label, which states "Cows injected with Posilac may have more enlarged hocks and disorders of the foot region" [132].

Recombinant bovine Somatotropin has also been shown to reduce the ability of cows to cope with high environmental temperatures, which can lead to heat stress $[113,133]$. It is, thus, not advisable in 
geographic regions where severe heat can be expected, especially if management options to alleviate heat stress are insufficient.

Clearly the use of rbST carries unintended risks to the welfare of animals, and these should be seriously considered before such growth-promoting compounds are touted as a possible mitigation strategy for climate change.

\subsection{Species Shifts}

In addition to increasing productivity within species, the current global trend toward intensively producing greater numbers of non-ruminant animals - pigs and chickens - is often viewed as a more efficient form of meat production compared to traditional ruminant cattle, sheep and goat rearing systems [134-136]. To meet the growing demand for animal protein in emerging economies [13], the expansion in supply is largely coming from increased local production, as opposed to from imports [12], and in these regions, livestock systems are rapidly shifting toward monogastric species. Pigs and poultry account for $77 \%$ of the expansion in production, a trend that is often accompanied by intensification, vertical integration, geographic concentration, up-scaling of production, and feeding more grain- or concentrate-based diets [12]—in short, industrialized farming.

Monogastrics have improved GHG efficiencies compared to cattle. Cattle accounted for $77 \%$ of total non- $\mathrm{CO}_{2} \mathrm{GHG}$ emissions from the livestock sector in 2000, while monogastrics accounted for just $10 \%$ [136]. It takes at least three times as much land to produce one kilogram of beef as it does to produce one kilogram of pork or chicken [137]. Cattle contribute about seven times the $\mathrm{CO}_{2}$-eq. emissions of pigs and chickens [2]. This biological difference can be explained by three main factors: greater feed efficiency, lower enteric $\mathrm{CH}_{4}$ emissions, and faster rates of reproduction. $\mathrm{CH}_{4}$ emissions from ruminants originate from both manure and enteric fermentation, while $\mathrm{CH}_{4}$ emissions from monogastrics are primarily associated with manure alone. Because sows and hens have a relatively large number of progeny and earlier sexual maturity, the number of breeding adults per animal slaughtered for human food is reduced in these production systems [137]. Together, these factors account for the reduction in inputs and lower emissions of pig and poultry production worldwide.

If the increasing consumption of animal protein in developing countries will be supplied in a substantial way by expansion of pork and chicken industries, and if the expansion will be in the form of specialized, intensive confinement facilities that typify the bulk of production in North America and other developed regions, then there is a serious potential for a concomitant increase in the animal welfare problems that characterize those systems.

As covered in Section 2.2.3, the intensive production of modern strains of poultry is the cause of one of the most severe and wide-spread animal welfare problems in the world. Globally, nearly 60 billion chickens are slaughtered for meat each year [138], and given the wide prevalence of metabolic problems and painful leg disorders, the intensive production of meat chickens already constitutes one of the most problematic aspects of intensive agriculture. Sweeping calls to use more of these compromised animals to meet efficiency goals is alarming.

In an ethical analysis, overall welfare would be a function of both the state of the individual animal and the number of animals subjected to that level of welfare. It takes far more animals to produce the 
same amount of meat when beef is replaced in the diet with chicken, compounding the overall magnitude of any negative animal welfare impacts.

Another of the most salient issues with intensive confinement of animals in agriculture is the way those animals are housed. Intensive systems for pork and poultry production remove animals from the land and instead raise them in indoor, total confinement facilities. While well-managed, large-scale production can have some animal welfare advantages, such as access to resources that might be economically out of reach to smaller producers, they often greatly limit the space allotment per animal. In the case of breeding sows in the pork production industry the animals are further partitioned into enclosures that prevent normal movement and severely restrict the animals' natural behavior, which is a serious welfare problem.

\subsubsection{Industrial Production of Pigs}

Swine are highly intelligent, social animals with complex behavioral repertoires. Yet, in many countries, intensive production facilities house female breeding pigs in narrow gestation crates, metal stalls that measure approximately $0.61 \mathrm{~m}$ by $2.31 \mathrm{~m}$, which is only slightly larger than the sow's own body. Each sow can take a step forward and backward, but she cannot turn around for the length of her pregnancy, which is approximately 114 days. Due to decreased fitness from chronic lack of exercise, crated sows have lower bone strength and muscle weight [139], and have higher resting heart rates [140], compared to those permitted more freedom of movement and exercise.

Fed concentrated grain-based diets that can be consumed quickly, and without opportunity to express species-typical foraging behavior, sows in intensive confinement operations often begin to display abnormal, stereotypic behavior including repetitive bar-biting, head-weaving, sham-chewing and drinker pressing. Rooted in stress and lack of stimulation [141,142], these "stereotypies", are common in captive animals kept in barren, restrictive environments [143]. Stereotypic behavior is often reduced when sows are fed a high fiber, bulky diet instead of, or in addition to, concentrates [144-148], although some fiber sources, such as soybean hulls, may be less effective [149]. Ethologists attribute this stereotypic behavior to boredom and frustration resulting from an impoverished environment, confinement, restraint, and unfulfilled behavioral needs [150,151].

Most large, industrialized confinement facilities for pigs utilize a liquid manure handling system with slatted floors. While a 2013 FAO review noted that slatted floor manure systems tend to decrease GHG and $\mathrm{NH}_{3}$ emissions compared with deep litter systems [10], these bare, concrete floors are hard on the animals' feet. One survey found that pigs allowed outdoor access had a lower prevalence of foot and limb injuries, while those confined indoors on hard, slatted flooring had more bruising, calluses, locomotion problems, and adventitious bursae [152]. The problem is especially acute for piglets; foot and limb injuries affect $60 \%$ to $90 \%$ of young piglets housed indoors, while only about $9 \%$ of piglets housed outdoors suffer these types of injuries. While outdoor production does have its own suite of welfare concerns, including severe weather and predators, in farrowing huts common to pasture-based systems, soil covered with straw provides a soft, non-abrasive, protective surface [152]. Behavioral testing has shown that pigs prefer earthen floors over concrete $[153,154]$. While bedding, such as straw provides comfort, warmth and outlets for natural rooting and nesting behavior, it is not usually provided in indoor operations due to cost, difficulty of cleaning, and incompatibility with slatted floors. 
There are however, more welfare-friendly intensive systems. For example, sows can successfully be housed in group pens as opposed to individual gestation crates, as long as they are managed well to prevent aggression. Group housing systems work best if they deliver the feed in a non-competitive way, such as by using trickle feeding, feeding stalls, or Electronic Sow Feeding systems (which use a computer to precisely deliver each sow's daily allotment) [155]. Straw bedding can be incorporated into these systems in purpose-built un-slatted sections of the barn. However, $\mathrm{N}_{2} \mathrm{O}$ emissions in a straw-based, deep litter group housing systems are usually greater compared to concrete slatted floors [156]. Further research on group housing systems design could focus on lowering emissions while simultaneously fulfilling the behavioral needs of the animals.

\subsubsection{Further Disadvantages of Shifting Production Systems}

Another problem with large, industrialized animal production sites is the ratio of animals to human caretakers. With increased farm size, new technologies and increased mechanization, such as automated feed and water delivery and manure removal, coupled with economic pressure to reduce labor, the result is that fewer workers now tend to more animals. As such, individualized attention to each animal is generally lacking. With the use of efficiencies in pen and barn design, one person may now be responsible for the care of 8000 pigs per day [157] (p. 291). One of the main daily tasks on a commercial-scale broiler grow-out facility is picking up the dead birds. While large farms can be well managed to reduce death losses, the health of the animals on large operations is often addressed at the herd or flock level, and individual veterinary care is not generally provided. An individual animal who becomes injured or ill is likely to go unnoticed, and could experience prolonged pain and suffering before their eventual death.

On top of the animal welfare concerns, the industrialization of agriculture carries with it numerous other societal implications. Switching to large-scale use of monogastrics threatens genetic diversity, and subsequent genetic adaptation of domestic species to climate change [158]. It could also mean the proliferation of more and more serious environmental issues, including air, soil, and water pollution. For example, the rapid expansion of pig production in the coastal areas of China, Vietnam, and Thailand is thought to be a major source of nutrient pollution in the South China Sea. Runoff is causing red tides and threatening fragile mangroves and coral reefs [12] (p. 71). Concerns such as these must be properly weighed in the discussion of intensification and shifts to monogastric production as proposed climate change mitigation strategies.

System changes, however, (e.g., from extensive to industrialized production) are not required for some of the most substantial emissions reductions, which can be achieved within production systems, across all species and regions. The FAO found that applying the techniques of $10 \%$ of the most efficient producers to current systems, by for example, improved pasture management and feed quality, and better animal health, among others could cut nearly a third of emissions from the farm animal sector. Production system changes further reduced emissions a mere 2\% [2] (pp. 45-46). Clearly, there is a large opportunity to improve emissions by picking the low-hanging fruit, i.e., the least efficient producers [2,159], while achieving multiple benefits, such as animal welfare, or at least avoiding additional negative impacts. Such improvements should also aim at improved food security (not just increased production) and fit well within the concept of "sustainable intensification" [160]. 


\section{Potential Solutions: Mitigation Strategies that both Improve Animal Welfare and Reduce Environmental Impacts}

While it is clear that animal welfare concerns for many different climate change mitigation strategies exist, fortunately a great many more potential solutions have benign or even beneficial welfare outcomes. Many of these options are strategies for extensive production, systems that, if improved, have very high welfare potential. Basic improvements to these systems would also have the co-benefit of improving the livelihoods of smallholder farmers. With more attention paid to the health, physiology, and behavioral effects on animals at the outset, triple-win strategies can be championed that mitigate climate change, improve food security, and improve animal welfare.

\subsection{Improved Animal Health and Longevity}

Where climate change solutions and improved animal welfare may dovetail best begins with a focus on the animals. Improving the efficiency of animal production systems by improving animal health and reducing mortality could reduce $\mathrm{CH}_{4}$ and $\mathrm{N}_{2} \mathrm{O}$ emissions considerably by reducing losses due to health related production declines and emissions attributed to animals that die before they can reproduce or produce consumable products. In locations where basic veterinary care, vaccinations, clean drinking water, shade, husbandry skills, technical knowledge, financial aid and other vital resources are lacking, there is great potential for improvement. For example, in many developing African and Asian countries, approximately $80 \%$ of poultry is still located in village flocks [161]. Globally, backyard flocks kept for meat and eggs contribute 42.5 million tons of $\mathrm{CO}_{2}$-eq. in greenhouse gas emissions and have higher emission intensity than intensively confined chickens, due in part to the low feed quality of scavenging birds and the toll that disease and predation take on productivity [2]. Vaccinations, providing simple, low-cost protection for newly hatched chicks from predators, supplementary feeding of balanced rations, and basic biosecurity education [162] could simultaneously improve the welfare of the flocks, alleviate poverty, and potentially reduce greenhouse gas emissions. The climate change mitigation potential of these improvements has not specifically been studied, to our knowledge.

Extending dairy cow lifetime is another potential improvement. Cows can easily live to 15 years of age or longer, but on most intensive, indoor dairy production facilities that typify developed countries the lifespan of a cow is typically closer to six years [163]. A USDA summary reports the proportion of dairy cows permanently removed from the herd for reproductive problems was $26.3 \%$; $23.0 \%$ were removed for udder or mastitis problems, $16.0 \%$ for lameness or injury, and $16.1 \%$ for poor production [52]. Similar factors for culling are reported for Canada and European countries [163]. In one study of 14 Irish dairy herds, the rate at which cows were replaced in the herd increased from $16 \%$ in 1990 to $27 \%$ in 2003, an increase of $0.8 \%$ per year, and the proportion of cows culled for infertility increased $2.2 \%$ per year, from $27 \%$ in 1990 to $40 \%$ in 2002 [164]. Improved longevity would reduce the total lifetime emissions of dairy cows when accounting for the resources needed for rearing replacement heifers. The proportion of total methane emissions produced by replacement heifers has been estimated to be up to $27 \%$ for U.K. dairy herds [165]. Relative to the period from birth to first calving (a period that usually lasts from 25 months to about 3 years, depending on the region), a greater number of lactation periods per lifetime will reduce overall $\mathrm{CH}_{4}$ loss per unit of milk yield [166]. By improving the lifespan of a dairy cow 
from 3.02 to 3.5 lactations, methane emissions would be reduced by 3\% [167]. Selection for increased productive life could also lead to a decrease in disease incidence of dairy cows [168].

In the future, one possibility for addressing the lack of individual attention on industrialized farms could be "Precision Livestock farming" (PLF). In PLF, sensors continuously monitor key indicators, such as animal movement, feed intake, or temperature and alert caretakers when a problem arises. Examples include using cameras to monitor the behavior of hens, pedometers to monitor estrus behavior of dairy cows, and automated scales for measuring weight gain of chickens [169]. PLF has good potential for automated detection of animal health problems. For example, auditory sensors can be used to detect disease in fattening pigs by analysis of coughing sounds, which change qualitatively when the respiratory system is infected [170,171]. However, it is uncertain how applicable these highly technical solutions would be in developing countries, and there is a danger of losing genuine husbandry skills and knowledge when relying even more heavily on automation.

\subsection{Improved Animal Nutrition}

As discussed previously, changes to animal diets can reduce greenhouse gas emissions and increase animal productivity, but they can also risk harming animal welfare. However, bolstering nutrition by supplementing poor diets or using improved forages can both reduce greenhouse gas emissions and improve welfare at the same time. In regions of the world with a seasonally dry tropical climate, such as Africa, the low nutritional value of most animal feeds during the dry season is a major constraint on animal productivity [172]. In developing countries, ruminant animals are often fed on low quality grasses and crop residues (stover). Inadequate nutrition is a key factor limiting fertility [10]. A large potential to mitigate emissions exists in these low-yield systems. For example, modeling of small ruminant production in West Africa suggests that improvements in forage digestibility, along with other animal health and husbandry measures, can potentially reduce emissions by $27 \%$ to $41 \%$ of baseline emissions, amounting to 7.7 to 12 million tons of $\mathrm{CO}_{2}$-eq. [2].

Improved forages can be used as a climate change mitigation strategy in both developing and developed regions. Legumes available for grazing ruminants in the United States include clover, alfalfa, crown vetch, and birdsfoot trefoil (lotus). These nutritionally valuable, high protein forages can be incorporated into established pasture or rangeland with interseeding. Not only can improved pastures reduce $\mathrm{CH}_{4}$ emissions from animals, but carbon sequestration in grassland soils can also be increased by planting nitrogen-fixing legumes [173-175].

The mitigation potential of feeding legumes has been the subject of a substantial number of studies. Simulation results in one study showed that $\mathrm{CH}_{4}$ production is $28 \%$ lower with legume forage (alfalfa hay) as compared to grass (timothy hay) when expressed as a proportion of gross energy (GE) intake, and $21 \%$ lower when expressed relative to digestible energy (DE) [176]. These results are corroborated by multiple field studies, which also find lower $\mathrm{CH}_{4}$ with pasture legumes for sheep [177] and cattle [178,179]. For example, Waghorn et al. (2002) found that when fed to sheep, a sulla/lucerne feed mixture produced just $19.0 \mathrm{~g} \mathrm{CH}_{4}$ per $\mathrm{kg}$ DMI compared to fresh pasture, which produced $25.7 \mathrm{~g}$ $\mathrm{CH}_{4}$ per kg DMI. In a second trial, lotus produced just $11.5 \mathrm{~g} \mathrm{CH}_{4}$ per $\mathrm{kg}$ DMI, and by using polyethylene glycol binding to remove condensed tannins (CT), the researchers demonstrated that CT played an important role in this reduction [177]. Condensed tannins not only lower $\mathrm{CH}_{4}$ production in sheep, but 
may also have other beneficial effects including improving wool growth and reducing intestinal worm burdens [180]. However, at least one study failed to find reduced methane production feeding white clover to sheep (Hammond et al., 2011) [181], and so more study is required.

One caution: legume consumption in some cases is associated with animal health issues, such as fetal hydrops in periparturient ewes [182], and bloat with some tropical legumes [183]. Feeding legumes must, therefore, be carefully managed to avoid animal health problems.

Many other feeding management strategies that can reduce greenhouse gas emissions without compromising animal welfare could be better emphasized and further explored. These include improving silage quality with more effective preservation methods [10]; adding dietary fats, such as coconut, linseed, soybean, or sunflower seed oils [184-186]; changes to pasture management such as matching grazing intensity and pasture quality [173,187] supplementation of the diet with enzymes [122,188] or yeasts [189], and precision feeding (better agreement between the supply of $\mathrm{N}$ in the diet and requirements of the animal, in order to reduce $\mathrm{N}$ excretion) [190,191], to name just a few.

\subsection{Improved Manure and Land Management}

In addition to improving animal health, nutrition or longevity, a great many more climate change mitigation options remain that could be used without negatively affecting the welfare of animals. Ruminants may be key parts to well-managed, mixed crop-livestock systems, helping to reduce a number of environmental impacts [192]. Well-managed grazing can improve soil organic carbon and nitrogen content [193] and partially offset net GHG emissions [194]. Most manure management options are probably welfare-neutral, unless collection systems require the intensive confinement of animals. Hristov et al. (2013) provide a thorough summary of such options including reducing manure storage time, composting, and carefully timed land application [10]. Several techniques for manure application also hold mitigation promise, for example subsurface application, application during non-rainy periods, and controlling soil $\mathrm{pH}$. Perennial crops can be used to improve soil structure, water retention capacity and, in turn, carbon sequestration capacity [195]. Converting from conventional tilling to conservation or no-till cropping practices, especially with the simultaneous use of cover crops, can reduce soil disturbance and improve soil biodiversity and is another way to sequester carbon [196]. Other options include restoration of degraded range land (re-vegetation, water conservation) [197,198], and silvopastoral and agroforestry systems $[198,199]$ among many others.

\subsection{Reduced Animal Numbers}

The demand for meat and dairy products is rapidly growing. This demand is attributable to the growing world population, urbanization and increasing affluence in emerging economies [200]. The projected global growth in annual consumption of meat and milk is $5.41 \%$ and $3.43 \%$, respectively. In Asia this growth is projected to be even greater, at $7.99 \%$ and $11.85 \%$ [201]. Meat consumption is expected to continue to grow in developing countries until they meet the levels of developed countries, with poultry accounting for around $50 \%$ of the increase [202]. If this demand is met, the growing number of animals will substantially increase the problem of climate change [203], even if production efficiencies per unit of product produced are realized. 
The growing demand for animal-based protein is usually presented as inevitable. While the general trajectory seems certain, the call to fill this demand in every case is not necessarily prudent. Reducing animal numbers could come, in part, with changes in production efficiency, as mentioned previously [2]. However, these production-side efficiency approaches seem, in some ways, to avoid the heart of the problem.

Feeding animals grain to produce animal-based food is inherently inefficient. For every $\mathrm{kg}$ of chicken live weight gain, $1.7 \mathrm{~kg}$ is required in feed, and chicken is the most highly feed efficient species; the ratio of feed to gain for pigs is 2.4 to 1 and for cattle it is as high as 10 to 1 [204]. The production of feed for animals can have a larger environmental impact in terms of energy use and global warming, than the management of those same animals and their manure on the farm [205,206]. Using IPCC figures, Garnett (2011) estimates that the reductions achievable for agriculture mitigation options amount to only about $30 \%$ of the total impact [207]; following this she argues: "[h]ence the conclusion that we need also to moderate our consumption of livestock products seems inescapable."

One approach to this is to address the immense amount of food that is wasted. This category is broad, including waste at harvest, storage, processing, and a number of post-consumer pathways [208]. The inefficiencies above suggest that waste of animal-based foods carries a particularly high environmental cost. The FAO has estimated global food waste at about $1 / 3$, with waste of meat products of about $20 \%$ [209]. Smith et al. (2013) found savings of about 6\% in food crop area, and 13\%-47\% GHG savings in 2050 through waste reduction compared to the reference case [210].

Another approach focuses specifically on consumption, particularly in developed countries and in populations that face chronic disease due to overconsumption. Many studies show that reducing consumption of animal products would have a substantial effect on reducing GHG emissions, and the IPCC recognized this potential in their Fifth Assessment Report [4]. Smith et al. (2013) found greater mitigation potential in the Agriculture, Forestry, and Other Land Use (AFOLU) sector on the consumption rather than production side, when incorporating associated benefits in spared land use (e.g., afforestation and bioenergy) [210].

While variables such as energy used in transport, processing and refrigeration do not permit blanket statements about animal products over alternatives, meat, seafood, and some dairy products tend to have large GHG emissions per kg of product at the checkout as compared to most plant-based foods [211]. Some analyses show that vegetarian and vegan diets have potential GHG savings of $22 \%$ and $29 \%$ in the UK and US, respectively [212,213]. However, a 2014 study conducted in the UK found that dietary GHG emissions for meat-eaters were approximately twice as high as those of vegans [214].

Vegan and vegetarian diets also have lower environmental impact including less land use [215], water [216], and fossil fuel requirements [217]. Reducing climate change mitigation costs [215], as well as potential to improve public health [218], have also been cited as a co-beneficial effects.

Substantial effects could be realized even by simply reducing meat consumption, such as through efforts like the Meatless Monday campaign [219], or partial substitution of plant protein in ground and processed meats [200]. Another potential future alternative is cultured meat production. Cultured meat is laboratory produced using in vitro tissue engineering techniques, and initial LCA estimates show that it could lead to 78\%-96\% lower GHG emissions than conventionally produced European meat [220], while simultaneously avoiding all of the animal welfare impacts of intensive production. 


\section{Conclusions}

Proposals for climate change mitigation strategies often use the term, "sustainable intensification." Yet, societal norms related to the way we treat animals and use them in agriculture are changing and some past practices are no longer as widely accepted. Intensification of animal farming may not ever truly be sustainable, unless, among other things, there is concomitant attention to the health and behavioral needs of the animals, a meaningful effort to provide them with a life worth living. There is an urgent need to integrate these other sustainability measures into GHG mitigation assessments [221].

While multiple approaches are necessary to help stop anthropogenic climate change, those that offer the largest potential climate and sustainability benefits, while avoiding negative tradeoffs, should be the focus. This could mean different approaches (and levels of focus) for pre-market (production side) versus the market and beyond (demand side). For example, with production-side measures, there can be a rapid marginalization of further climate benefits beyond initial productivity gains [159]. Demand-side approaches, on the other hand, seem to offer a largely untapped potential with multiple co-benefits.

More research is needed to explore the combination of animal welfare and environmental improvements. There are some promising examples in pigs [222], chickens [223], and dairy cows [224,225]. These studies exhibit potential and the factors dictating these results, as well as ways to improve upon them, should be the focus of future research agendas.

Calls to globalize the production systems that were developed in the West are concerning when the impacts on the animals are taken into account, and there is worldwide momentum toward abandoning the worst practices. For example, multinational corporations such as McDonalds, Compass Group, and Nestle are asking producers for plans to eliminate gestation crates from their supply chains. Legislative and voluntary phase-outs of intensive animal confinement systems are increasingly taking hold across the globe, for example in the European Union, South Africa, Australia, Canada, New Zealand and several US states, with active campaigns in many additional regions of the world. The global movement toward farm animal welfare reform must be an important consideration going forward in the discussion of climate change mitigation strategies, and research and policy should increasingly reflect this.

\section{Acknowledgments}

We would like to thank Mike Appleby for initial edits and comments.

\section{Author Contributions}

Shields and Orme-Evans researched and wrote the manuscript.

\section{Conflicts of Interest}

The authors work in the Farm Animals section of Humane Society International. 


\section{References}

1. IPCC. Summary for policymakers. In Climate Change 2014: Impacts, Adaptation, and Vulnerability. Part A: Global and Sectoral Aspects. Contribution of Working Group II to the Fifth Assessment Report of the Intergovernmental Panel on Climate Change; Field, C.B., Barros, V.R., Dokken, D.J., Mach, K.J., Mastandrea, M.C., Bilir, T.E., Chatterjee, M., Ebi, K.L., Estrada, Y.O., Genova, R.C., et al., Eds.; Cambridge University Press: New York, NY, USA, 2014; pp. 1-32.

2. Gerber, P.J.; Steinfeld, H.; Henderson, B.; Mottet, A.; Opio, C.; Dijkman, J.; Falcucci, A.; Tempio, G. Tackling Climate Change through Livestock-A Global Assessment of Emissions and Mitigation Opportunities; Food and Agriculture Organization of the United Nations: Rome, Italy, 2013.

3. Place, S.E.; Mitloehner, F.M. The nexus of environmental quality and livestock welfare. Аnnu. Rev. Anim. Biosci. 2014, 2, 555-569. [CrossRef] [PubMed]

4. Smith, P.; Bustamante, M.; Ahammad, H.; Clark, H.; Dong, H.; Elsiddig, E.A.; Haberl, H.; Harper, R.; House, J.; Jafari, M.; et al. Agriculture, forestry, and other land use (AFOLU). In Climate Change 2014: Mitigation of Climate Change. Contribution of Working Group III to the Fifth Assessment Report of the Intergovernmental Panel on Climate Change; Edenhofer, O., Pichs-Madruga, R., Sokona, Y., Farahani, E., Kadner, S., Seyboth, K., Adler, A., Baum, I., Brunner, S., Eickemeier, P., et al., Eds.; Cambridge University Press: New York, NY, USA, 2014; pp. 811-922.

5. Challenges and Opportunities for Mitigation in the Agricultural Sector; United Nations, Framework Convention on Climate Change, Technical Paper. 2008. Available online: http://unfccc.int/resource/docs/2008/tp/08.pdf (accessed on 14 May 2015).

6. Duncan, I.J.H. Science-based assessment of animal welfare: Farm animals. Rev. Sci. Tech. 2005, 24, 483-492. [PubMed]

7. IPCC. Climate Change 2013: The Physical Science Basis. Contribution of the Working Group I to the Fifth Assessment Report of the Intergovernmental Panel on Climate Change; Cambridge University Press: Cambridge, UK; New York, NY, USA, 2013.

8. IPCC. Summary for policymakers. In Climate Change 2013: The Physical Science Basis. Contribution of Working Group I to the Fifth Assessment Report of the Intergovernmental Panel on Climate Change; Stocker, T.F., Qin, D., Plattner, G.-K., Tignor, M., Allen, S.K., Boschung, J., Nauels, A., Xia, Y., Bex, V., Midgley, P.M., et al., Eds.; Cambridge University Press: New York, NY, USA, 2013.

9. IPCC. Summary for policymakers. In Climate Change 2014: Mitigation of Climate Change. Contribution of Working Group III to the Fifth Assessment Report of the Intergovernmental Panel on Climate Change; Edenhofer, O., Pichs-Madruga, R., Sokona, Y., Farahani, E., Kadner, S., Seyboth, K., Adler, A., Baum, I., Brunner, S., Eickemeier, P., et al., Eds.; Cambridge University Press: New York, NY, USA, 2014.

10. Hristov, A.N.; Oh, J.; Lee, C.; Meinen, R.; Montes, F.; Ott, T.; Firkins, J.; Rotz, A.; Dell, C.; Adesogan, A.; et al. Mitigation of Greenhouse Gas Emissions in Livestock Production-A Review

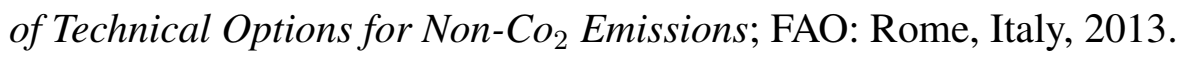


11. Gerber, P.; Key, N.; Portet, F.; Steinfeld, H. Policy options in addressing livestock's contribution to climate change. Animal 2010, 4, 393-406. [CrossRef] [PubMed]

12. Steinfeld, H.; Gerber, P.; Wassenaar, T.; Castel, V.; Rosales, M.; de Haan, C. Livestock's Long Shadow: Environmental Issues and Options; Food and Agriculture Organization of the United Nations: Rome, Italy, 2006.

13. IPCC. Climate Change 2007: Mitigation of Climate Change. Contribution of Working Group III to the Fourth Assessment Report of the Intergovernmental Panel on Climate Change; Cambridge University Press: Cambridge, UK; New York, NY, USA, 2007.

14. Millen, D.D.; Pacheco, R.D.L.; Meyer, P.M.; Mazza Rodrigues, P.H.; de Beni Arrigoni, M. Current outlook and future perspectives of beef production in Brazil. Anim. Front. 2011, 1, 46-52; [CrossRef] citing ANUALPEC. Anuário da Pecuária Brasileira, 41st ed.; Instituto FNP and Agra Pesquisas Ltda: São Paulo, Brazil, 2011.

15. SCAHAW. The Welfare of Cattle Kept for Beef Production; Scientific Committee on Animal Health and Animal Welfare, European Commission, Health \& Consumer Protection Directorate-General, 2001. Available online: http://ec.europa.eu/food/fs/sc/scah/out54_en.pdf (accessed on 14 May 2015).

16. Cheng, K.J.; McAllister, T.A.; Popp, J.D.; Hristov, A.N.; Mir, Z.; Shin, H.T. A review of bloat in feedlot cattle. J. Anim. Sci. 1998, 76, 229-308.

17. Millen, D.D.; Pacheco, R.D.L.; Meyer, P.M.; Rodrigues, P.H.M.; Arrigoni, M.D.B. Current outlook and future perspectives of beef production in Brazil. Anim. Front. 2011, 1, 46-52; [CrossRef] citing Oliveira, C.; Millen, D.D. Survey of nutritional recommendations and management practices used by Brazilian feedlot consulting nutritionists: General information and adaptation. In Proceedings of the 48th Annual Meeting of Brazilian Animal Science Society, Belém, Brazil, 2011.

18. Greenough, P.R.; Vermunt, J.J.; McKinnon, J.J.; Fathy, F.A.; Berg, P.A.; Cohen, D.H. Laminitis-like changes in the claws of feedlot cattle. Can. Vet. J. 1990, 31, 202-208. [PubMed]

19. Glock, R.D.; DeGroot, B.D. Sudden death of feedlot cattle. J. Anim. Sci. 1998, 76, 315-319. [PubMed]

20. Smith, R.A. Impact of disease on feedlot performance: A review. J. Anim. Sci. 1998, 272-274.

21. Owens, F.N.; Secrist, D.S.; Hill, W.J.; Gill, D.R. Acidosis in cattle: A review. J. Anim. Sci. 1998, 76, 275-286. [PubMed]

22. USDA. Beef 2007-2008, Part II: Reference of Beef Cow-Calf Management Practices in the United States, 2007-2008; USDA-APHIS-VS-CEAH: Fort Collins, CO, USA, 2009; p. 110.

23. Trunkfield, H.R.; Broom, D.M. The welfare of calves during handling and transport. Appl. Anim. Behav. Sci. 1990, 28, 135-152. [CrossRef]

24. Swanson, J.C.; Morrow-Tesch, J. Cattle transport: Historical, research, and future perspectives. J. Anim. Sci. 2001, 79, E102-E109.

25. Fike, K.; Spire, M.F. Transportation of cattle. Vet. Clin. N. Am. Food Anim. Pract. 2006, 22, 305-320. [CrossRef]

26. Schwartzkopf-Genswein, K.S.; Booth-McLean, M.E.; Shah, M.A.; Entz, T.; Bach, S.J.; Mears, G.J.; Schaefer, A.L.; Cook, N.; Church, J.; McAllister, T.A.; et al. Effects of pre-haul 
management and transport duration on beef calf performance and welfare. Appl. Anim. Behav. Sci. 2007, 108, 12-30.

27. White, B.J.; Blasi, D.; Vogel, L.C.; Epp, M. Associations of beef calf wellness and body weight gain with internal location in a truck during transportation. J. Anim. Sci. 2009, 87, 4143-4150. [CrossRef] [PubMed]

28. Mackenzie, A.M.; Drennan, M.; Rowan, T.G.; Dixon, J.B.; Carter, S.D. Effect of transportation and weaning on humoral immune responses of calves. Res. Vet. Sci. 1997, 63, 227-230. [CrossRef] [PubMed]

29. Carroll, J.A.; Forsberg, N.E. Influence of stress and nutrition on cattle immunity. Vet. Clin. N. Am. Food Anim. Pract. 2007, 23, 105-149. [CrossRef]

30. Nielsen, B.L.; Thodberg, K.; Dybkjaer, L.; Vestergaard, E.M. Feeding behaviour in pigs. In Feeding in Domestic Vertebrates: From Structure to Behaviour; Bels, V., Ed.; CAB International: Wallingford, UK, 2006; pp. 156-178.

31. Millet, S.; Kumar, S.; de Boever, J.; Ducatelle, R.; de Brabander, D. Effect of feed processing on growth performance and gastric mucosa integrity in pigs from weaning until slaughter. Anim. Feed Sci. Technol. 2012, 175, 175-181. [CrossRef]

32. Amory, J.R.; Mackenzie, A.M.; Pearce, G.P. Factors in the housing environment of finisher pigs associated with the development of gastric ulcers. Vet. Rec. 2006, 158, 260-264. [CrossRef] [PubMed]

33. Robertson, I.D.; Accioly, J.M.; Moore, K.M.; Driesen, S.J.; Pethick, D.W.; Hampson, D.J. Risk factors for gastric ulcers in australian pigs at slaughter. Prev. Vet. Med. 2002, 53, 293-303. [CrossRef] [PubMed]

34. Majekodunmi, M.M.; Omotosho, O.O.; Emikpe, B.O.; Olufemi, B.E. The incidence of gastric lesions in slaughtered pigs in Ibadan, Nigeria. Sokoto J. Vet. Sci. 2013, 11, 22-27.

35. De Oliveira, S.J.; Bernardi, R.T.; Vogt, F.I.; Scartezzini, M.; Hepp, D.; Lunge, V.R. Gastric ulcers in fattening pigs: Isolation of Arcobacter spp. From stomachs with different severity of lesions. Acta Sci. Vet. 2010, 38, 351-356.

36. Swaby, H.; Gregory, N.G. A note on the frequency of gastric ulcers detected during post-mortem examination at a pig abattoir. Meat Sci. 2012, 90, 269-271. [CrossRef] [PubMed]

37. Friendship, R.M. Gastric ulcers: An under-recognized cause of mortality and morbidity. Adv. Pork Prod. 2003, 14, 159-164.

38. Nielsen, E.K.; Ingvartsen, K.L. Effects of cereal disintegration method, feeding method and straw as bedding on stomach characteristics including ulcers and performance in growing pigs. Acta Agric. Scand. Sect. A Anim. Sci. 2000, 50, 30-38.

39. Ramis, G.; Gómez, S.; Pallarés, F.J.; Muñoz, A. Comparison of the severity of esophagogastric, lung and limb lesions at slaughter in pigs reared under standard and enriched conditions. Anim. Welf. 2005, 14, 27-34.

40. Newbold, C.J.; López, S.; Nelson, N.; Ouda, J.O.; Wallace, R.J.; Moss, A.R. Proprionate precursors and other metabolic intermediates as possible alternative electron acceptors to methanogenesis in ruminal fermentation in vitro. Br. J. Nutr. 2005, 94, 27-35. [CrossRef] [PubMed] 
41. Alaboudi, R.; Jones, G.A. Effects of acclimation to high nitrate intake on some rumen fermentation parameters in sheep. Can. J. Anim. Sci. 1985, 65, 841-849. [CrossRef]

42. Schoonmaker, J.P.; Beitz, D.C. Hydrogen Sulphide: Synthesis, Physiology, Roles and Pathology Associated with Feeding Cattle Maize Co-Products of the Ethanol Industry. In Biofuel Co-Products as Livestock Feed: Opportunities and Challenges; FAO: Rome, Italy, 2012; pp. 101-113.

43. Wall, E.; Simm, G.; Moran, D. Developing breeding schemes to assist mitigation of greenhouse gas emissions. Animal 2010, 4, 366-376. [CrossRef] [PubMed]

44. Capper, J.L.; Cady, R.A.; Bauman, D.E. The environmental impact of dairy production: 1944 compared with 2007. J. Anim. Sci. 2009, 87, 2160-2167. [CrossRef] [PubMed]

45. Hristov, A.N.; Ott, T.; Tricarico, J.; Rotz, A.; Waghorn, G.; Adesogan, A.; Dijkstra, J.; Montes, F.; Oh, J.; Kebreab, E.; et al. Mitigation of methane and nitrous oxide emissions from animal operations: III. A review of animal management mitigation options. J. Anim. Sci. 2013, 91, 5095-5113.

46. Rauw, W.M.; Kanis, E.; Noordhuizen-Stassen, E.N.; Grommers, F.J. Undesirable side effects of selection for high production efficiency in farm animals: A review. Livest. Prod. Sci. 1998, 56, 15-33. [CrossRef]

47. Veerkamp, R.F.; Oldenbroek, J.K.; van der Gaast, H.J.; van der Werf, J.H.J. Genetic correlation between days until start of luteal activity and milk yield, energy balance and live weights. J. Dairy Sci. 2000, 83, 577-583. [CrossRef] [PubMed]

48. Collard, B.L.; Boettcher, P.J.; Dekkers, J.C.M.; Peticlerc, D.; Schaeffer, L.R. Relationships between energy balance and health traits of dairy cattle in early lactation. J. Dairy Sci. 2000, 83, 2683-2690. [CrossRef] [PubMed]

49. Van Dorp, T.E.; Dekkers, J.C.M.; Martin, S.W.; Noordhuizen, J.P.T.M. Genetic parameters of health disorders, and relationships with 305-day milk yield and conformation traits of registered Holstein cows. J. Dairy Sci. 1998, 81, 2264-2270. [CrossRef] [PubMed]

50. Fleischer, P.; Metzner, M.; Beyerbach, M.; Hoedemaker, M.; Klee, W. The relationship between milk yield and the incidence of some diseases in dairy cows. J. Dairy Sci. 2001, 84, 2025-2035. [CrossRef] [PubMed]

51. Goff, J.P. Major advances in our understanding of nutritional influences on bovine health. J. Dairy Sci. 2006, 89, 1292-1301. [CrossRef] [PubMed]

52. USDA. Dairy 2007, Part I: Reference of Dairy Cattle Health and Management Practices in the United States; \#N480.1007; USDA-APHIS-VS-CEAH: Fort Collins, CO, USA, 2007.

53. White, T.C.; Madsen, K.S.; Hintz, R.L.; Sorbet, R.H.; Collier, R.J.; Hard, D.L.; Hartnell, G.F.; Samuels, W.A.; de Kerchove, G.; Adriaens, F.; et al. Clinical mastitis in cows treated with somatribove (recombinant bovine somatotropin) and its relationship to milk yield. J. Dairy Sci. 1994, 77, 2249-2260.

54. Hagiya, K.; Yamazaki, T.; Nagamine, Y.; Togashi, K.; Yamaguchi, S.; Gotoh, Y.; Kawahara, T.; Masuda, Y.; Suzuki, M. Genetic correlations between production and disease traits during first lactation in Holstein cows. Animal 2014, 8, 217-223. [CrossRef] [PubMed]

55. Pritchard, T.; Coffey, M.; Mrode, R.; Wall, E. Genetic parameters for production, health, fertility and longevity traits in dairy cows. Animal 2013, 7, 34-46. [CrossRef] [PubMed] 
56. Hinrichs, D.; Stamer, E.; Junge, W.; Kalm, E. Genetic analyses of mastitis data using animal threshold models and genetic correlation with production traits. J. Dairy Sci. 2005, 88, 2260-2268. [CrossRef] [PubMed]

57. Carlén, E.; Strandberg, E.; Roth, A. Genetic parameters for clinical mastitis, somatic cell score, and production in the first three lactations of swedish Holstein cows. J. Dairy Sci. 2004, 87, 3062-3070. [CrossRef] [PubMed]

58. Kadarmideen, H.N.; Thompson, R.; Simm, G. Linear and threshold model genetic parameters for disease, fertility and milk production in dairy cattle. Anim. Sci. 2000, 71, 411-419.

59. Amin, A.A.; Gere, T. Genetic parameters of udder, mastitis and milk traits in two different climactic areas using animal model analysis. Czech J. Anim. Sci. 2000, 45, 193-199.

60. Bell, M.J.; Wall, E.; Russell, G.; Simm, G.; Stott, A.W. The effect of improving cow productivity, fertility, and longevity on the global warming potential of dairy systems. J. Dairy Sci. 2011, 94, 3662-3678. [CrossRef] [PubMed]

61. Dong, G.; Liu, S.; Wu, Y.; Lei, C.; Zhou, J.; Zhang, S. Diet-induced bacterial immunogens in the gastrointestinal tract of dairy cows: Impacts on immunity and metabolism. Acta Vet. Scand. 2011. [CrossRef]

62. Kleen, J.L.; Hooijer, G.A.; Rehage, J.; Noordhuizen, J.P.T.M. Subacute ruminal acidosis (SARA): A review. J. Vet. Med. A 2003, 50, 406-414. [CrossRef]

63. Saleem, F.; Ametaj, B.N.; Bouatra, S.; Mandal, R.; Zebeli, Q.; Dunn, S.M.; Wishart, D.S. A metabolomics approach to uncover the effects of grain diets on rumen health in dairy cows. J. Dairy Sci. 2012, 95, 6606-6623. [CrossRef] [PubMed]

64. Boyd, G.; Cady, R. A 50-Year Comparison of the Carbon Footprint of the US Swine Herd: 1959-2009. Camco, 2012. Available online: http://old.pork.org/filelibrary/researchdocuments/ 10-174-boyd-camco-final-5-22-12.pdf (accessed on 14 May 2015).

65. Su, G.; Lund, M.S.; Sorensen, D. Selection for litter size at day five to improve litter size at weaning and piglet survival rate. J. Anim. Sci. 2007, 85, 1385-1392. [CrossRef] [PubMed]

66. Edwards, S.A. Perinatal mortality in the pig: Environmental or physiological solutions? Livest. Prod. Sci. 2002, 78, 3-12. [CrossRef]

67. Herpin, P.; le Dividich, J.; Amaral, N. Effect of selection for lean tissue growth on body composition and physiological state of the pig at birth. J. Anim. Sci. 1993, 71, 2645-2653. [PubMed]

68. Rydhmer, L.; Lundeheim, N. Breeding pigs for improved welfare. In Welfare of Pigs from Birth to Slaughter; Faucitano, L., Schaefer, A.L., Eds.; Wageningen Academic Publishers: Wageningen, The Netherlands, 2008; pp. 243-270.

69. Bergeron, R.; Badnell-Waters, A.J.; Lambton, S.; Mason, G. Stereotypic oral behaviour in captive ungulates: Foraging, diet and gastrointestinal function. In Stereotypic Animal Behaviour: Fundamentals and Applications to Welfare, 2nd ed.; Mason, G., Rushen, J., Eds.; CAB International: Wallingford, UK, 2006; pp. 19-57.

70. Hutson, G.D. A comparison of operant responding by farrowing sows for food and nest-building materials. Appl. Anim. Behav. Sci. 1992, 34, 221-230. [CrossRef]

71. Lawrence, A.B.; Illius, A.W. Methodology for measuring hunger and food needs using operant conditioning in the pig. Appl. Anim. Behav. Sci. 1989, 24, 273-285. [CrossRef] 
72. Zuidhof, M.J.; Schneider, B.L.; Carney, V.L.; Korver, D.R.; Robinson, F.E. Growth, efficiency, and yield of commercial broilers from 1957, 1978, and 2005. Poult. Sci. 2014, 93, 1-13. [CrossRef] [PubMed]

73. Jones, H.E.; Warkup, C.C.; Williams, A.; Audsley, E. The effect of genetic improvement on emission from livestock systems. In Proceedings of the 59th Annual Meeting of the European Association for Animal Production, Vilnius, Lithuania, 24-27 August 2008; Wageningen Academic Publishers: Vilnius, Lithuania, 2008; Volume 14, p. 28.

74. Bessei, W. Welfare of broilers: A review. World's Poult. Sci. J. 2006, 62, 455-466. [CrossRef]

75. Sanotra, G.S.; Lund, J.D.; Ersbøll, A.K.; Petersen, J.S.; Vestergaard, K.S. Monitoring leg problems in broilers: A survey of commercial broiler production in Denmark. World's Poult. Sci. J. 2001, 57, 55-69. [CrossRef]

76. Julian, R.J. Production and growth related disorders and other metabolic diseases of poultry-A review. Vet. J. 2005, 169, 350-369. [CrossRef] [PubMed]

77. Knowles, T.G.; Kestin, S.C.; Haslam, S.M.; Brown, S.N.; Green, L.E.; Butterworth, A.; Pope, S.J.; Pfeiffer, D.; Nicol, C.J. Leg disorders in broiler chickens: Prevalence, risk factors and prevention. PLoS ONE 2008, 3, e1545. [CrossRef] [PubMed]

78. Kestin, S.C.; Knowles, T.G.; Tinch, A.E.; Gregory, N.G. Prevalence of leg weakness in broiler chickens and its relationship with genotype. Vet. Rec. 1992, 131, 190-194. [CrossRef] [PubMed]

79. Skinner-Noble, D.O.; Teeter, R.G. An examination of anatomic, physiologic, and metabolic factors associated with well-being of broilers differing in field gait score. Poult. Sci. 2009, 88, 2-9. [CrossRef] [PubMed]

80. Danbury, T.C.; Weeks, C.A.; Chambers, J.P.; Waterman-Pearson, A.E.; Kestin, S.C. Self-selection of the analgesic drug carprofen by lame broiler chickens. Vet. Rec. 2000, 146, 307-311. [CrossRef] [PubMed]

81. Nääs, I.A.; Paz, I.C.L.A.; Baracho, M.S.; Menezes, A.G.; Bueno, L.G.F.; Almeida, I.C.L.; Moura, D.J. Impact of lameness on broiler well-being. J. Appl. Poult. Res. 2009, 18, 432-439. [CrossRef]

82. McGeown, D.; Danbury, T.C.; Waterman-Pearson, A.E.; Kestin, S.C. Effect of carprofen on lameness in broiler chickens. Vet. Rec. 1999, 144, 668-671. [CrossRef] [PubMed]

83. Boersma, S. Managing rapid growth rate in broilers. World Poult. 2001, 17, 20-21.

84. Julian, R.J. Evaluating the impact of metabolic disorders on the welfare of broilers. In Measuring and Auditing Broiler Welfare; Weeks, C., Butterworth, A., Eds.; CABI Publishing: Wallingford, UK, 2004; pp. 51-59.

85. Gonzales, E.; Buyse, J.; Takita, T.S.; Sartori, J.R.; Decuypere, E. Metabolic disturbances in male broilers of different strains. 1: Performance, mortality, and right ventricular hypertrophy. Poult. Sci. 1998, 77, 1646-1653.

86. Gardiner, E.E.; Hunt, J.R.; Newberry, R.C.; Hall, J.W. Relationships between age, body weight, and season of the year and the incidence of sudden death syndrome in male broiler chickens. Poult. Sci. 1988, 67, 1243-1249. [CrossRef] [PubMed]

87. EFSA. Scientific opinion on welfare aspects of the management and housing of the grand-parent and parent stocks raised and kept for breeding purposes. EFSA J. 2010. [CrossRef] 
88. Hocking, P.M. Measuring and auditing the welfare of broiler breeders. In Measuring and Auditing Broiler Welfare; Weeks, C.A., Butterworth, A., Eds.; CABI Publishing: Wallingford, UK, 2004; pp. 19-36.

89. Burkhart, C.A.; Cherry, J.A.; van Krey, H.P.; Siegel, P.B. Genetic selection for growth rate alters hypothalamic satiety mechanisms in chickens. Behav. Genet. 1983, 13, 295-300. [CrossRef] [PubMed]

90. Buckley, L.A.; McMillan, L.M.; Sandilands, V.; Tolkamp, B.J.; Hocking, P.M.; D’Eath, R.B. Too hungry to learn? Hungry broiler breeders fail to learn a Y-maze food quantity discrimination task. Anim. Welf. 2011, 20, 469-481.

91. Hocking, P.M.; Maxwell, M.H.; Mitchell, M.A. Relationships between the degree of food restriction and welfare indices in broiler breeder females. Br. Poult. Sci. 1996, 37, 263-278. [CrossRef] [PubMed]

92. De Jong, I.C.; Guémené, D. Major welfare issues in broiler breeders. World's Poult. Sci. J. 2011, 67, 73-82. [CrossRef]

93. Savory, C.J.; Maros, K.; Rutter, S.M. Assessment of hunger in growing broiler breeders in relation to a commercial restricted feeding programme. Anim. Welf. 1993, 131-152.

94. Mench, J.A. Broiler breeders: Feed restriction and welfare. World's Poult. Sci. J. 2002, 58, 23-29. [CrossRef]

95. De Jong, I.C.; Jones, B. Feed restriction and welfare in domestic birds. In Feeding in Domestic Vertebrates: From Structure to Behaviour; Bels, V., Ed.; CAB International: Wallingford, UK, 2006; pp. 120-135.

96. Savory, C.J.; Wood-Gush, D.G.M.; Duncan, I.J.H. Feeding behaviour in a population of domestic fowls in the wild. Appl. Anim. Ethol. 1978, 4, 13-27. [CrossRef]

97. Dawkins, M.S. Time budgets in red junglefowl as a baseline for the assessment of welfare in domestic fowl. Appl. Anim. Behav. Sci. 1989, 24, 77-80. [CrossRef]

98. Savory, C.J.; Maros, K. Influence of degree of food restriction, age and time of day on behaviour of broiler breeder chickens. Behav. Process. 1993, 29, 179-190. [CrossRef]

99. Hocking, P.M. Feed restriction. In Biology of Breeding Poultry; Poultry Science Symposium Series; Hocking, P.M., Ed.; CAB International: Wallingford, UK, 2009; Volume 29, pp. 307-330.

100. Dawkins, M.S.; Layton, R. Breeding for better welfare: Genetic goals for broiler chickens and their parents. Anim. Welf. 2012, 21, 147-155. [CrossRef]

101. Waghorn, G.C.; Hegarty, R.S. Lowering ruminant methane emissions through improved feed conversion efficiency. Anim. Feed Sci. Technol. 2011, 166-167, 291-301.

102. Pinares-Patino, C.S.; Hickey, S.M.; Young, E.A.; Dodds, K.G.; MacLean, S.; Molano, G.; Sandoval, E.; Kjestrup, H.; Harland, R.; Hunt, C.; et al. Heritability estimates of methane emissions from sheep. Animal 2013, 7, 316-321.

103. Eisler, M.C.; Lee, M.R.F.; Tarlton, J.F.; Martin, G.B.; Beddington, J.; Dungait, J.A.J.; Greathead, H.; Liu, J.; Mathew, S.; Miller, H.; et al. Agriculture: Steps to sustainable livestock. Nature 2014, 507, 32-34.

104. Murray, M.; Trail, J.C.; Davis, C.E.; Black, S.J. Genetic resistance to African trypanosomiasis. J. Infect. Dis. 1984, 149, 311-319. [CrossRef] [PubMed] 
105. Madalena, F.E. How sustainable are the breeding programs of the global main stream dairy breeds?-The latin-american situation. Livest. Res. Rural Dev. 2008, 20, Article \#19.

106. Berman, A. Invited review: Are adaptions present to support dairy cattle productivity in warm climates? J. Dairy Sci. 2011, 94, 2147-2158. [CrossRef] [PubMed]

107. Thornton, P.K. Livestock production: Recent trends, future prospects. Philos. Trans. R. Soc. B 2010, 365, 2853-2867. [CrossRef]

108. Capper, J.; Castaneda-Gutiérrez, E.; Cady, R.A.; Bauman, D.A. The environmental impact of recombinant bovine somatotropin (rbST) use in dairy production. Proc. Natl. Acad. Sci. USA 2008, 105, 9668-9673. [CrossRef] [PubMed]

109. Stackhouse, K.R.; Rotz, C.A.; Oltjen, J.W.; Mitloehner, F.M. Growth-promoting technologies decrease the carbon footprint, ammonia emissions, and costs of california beef production systems. J. Anim. Sci. 2012, 90, 4656-4665. [CrossRef] [PubMed]

110. Loneragan, G.H.; Thomson, D.U.; Scott, H.M. Increased mortality in groups of cattle administered the b-adrenergic agonists ractopamine hydrochloride and zilpaterol hydrochloride. PLOS ONE 2014, 9, e91177. [CrossRef] [PubMed]

111. Lean, I.J.; Thompson, J.M.; Dunshea, F.R. A meta-analysis of zilpaterol and ractopamine effects on feedlot performance, carcass traits and shear strength of meat in cattle. PLoS ONE 2014, 9, e115904. [CrossRef] [PubMed]

112. Dohoo, I.R.; Leslie, K.; DesCôteaux, L.; Fredeen, A.; Dowling, P.; Preston, A.; Shewfelt, W. A meta-analysis review of the effects of recombinant bovine somatotropin: 1. Methodology and effects on production. Can. J. Vet. Res. 2003, 67, 241-251.

113. SCAHAW. Report on Animal Welfare Aspects of the Use of Bovine Somatotrophin; Scientific Committee on Animal Health and Animal Welfare, 1999. Available online: http://ec.europa.eu/ food/fs/sc/scah/out21_en.pdf (accessed on 14 May 2015).

114. Cooprider, K.L.; Mitloehner, F.M.; Famula, T.R.; Kebreab, E.; Zhao, Y.; van Eenennaam, A.L. Feedlot efficiency implications on greenhouse gas emissions and sustainability. J. Anim. Sci. 2011, 89, 2643-2656. [CrossRef] [PubMed]

115. Stackhouse-Lawson, K.R.; Tucker, C.B.; Calvo-Lorenzo, M.S.; Mitloehner, F.M. Effects of growth-promoting technology on feedlot cattlebehavior in the 21 days before slaughter. Appl. Anim. Behav. Sci. 2015, 162, 1-8. [CrossRef]

116. Froman, M. Report on Sanitary and Phytosanitary Measures; United States Trade Representative: Washington, DC, USA, 2014.

117. Marchant-Forde, J.N.; Lay, D.C., Jr.; Pajor, E.A.; Richert, B.T.; Schinckel, A.P. The effects of ractopamine on the behavior and physiology of finishing pigs. J. Anim. Sci. 2003, 81, 416-422. [PubMed]

118. Poletto, R.; Cheng, H.W.; Meisel, R.L.; Richert, B.T.; Marchant-Forde, J.N. Effects of ractopamine feeding, gender and social rank on aggressiveness and monoamine concentrations in different brain areas of finishing pigs. In Proceedings of the 42nd Congress of the ISAE, Dublin, Ireland, 5-9 August 2008; Boyle, L., O’Connell, N., Hanlon, A., et al., Eds.; International Society for Applied Ethology: Dublin, Ireland, 2008. 
119. Poletto, R.; Richert, B.T.; Marchant-Forde, J.N. Behavioral effects of "step-up" ractopamine feeding program on finishing pigs. In Proceedings of the 41st International Congress of the ISAE, Merida, Mexico, 3 August 2007; Galindo, F., Alvarez, L., Eds.; International Society for Applied Ethology: Merida, Mexico, 2007; p. 90.

120. Poletto, R.; Rostagno, M.H.; Richert, B.T.; Marchant-Forde, J.N. Effects of a "step-up" ractopamine feeding program, sex, and social rank on growth performance, hoof lesions, and enterobacteriaceae shedding in finishing pigs. J. Anim. Sci. 2009, 87, 304-313. [CrossRef] [PubMed]

121. Annexstad, R.J.; Otterby, D.E.; Linn, J.G.; Hansen, W.P.; Soderholm, C.G.; Wheaton, J.E. Somatotropin treatment for a second consecutive lactation. J. Dairy Sci. 1990, 73, 2423-2436. [CrossRef] [PubMed]

122. Williams, P.E.W. Animal production and european pollution problems. Anim. Feed Sci. Technol. 1995, 53, 135-144. [CrossRef]

123. Burton, J.H.; MacLeod, G.K.; McBride, B.W.; Burton, J.L.; Bateman, K.; McMillan, I.; Eggert, R.G. Overall efficacy of chronically administered recombinant bovine somatotropin to lactating dairy cows. J. Dairy Sci. 1990, 73, 2157-2167. [CrossRef] [PubMed]

124. Pell, A.N.; Tsang, D.S.; Howlett, B.A.; Juyle, M.T.; Meserole, V.K.; Samuels, W.A.; Hartnell, G.F.; Hint, R.L. Effects of a prolonged-release formulation of sometribove ( $N$-methionyl bovine somatotropin) on jersey cows. J. Dairy Sci. 1992, 75, 3416-3431. [CrossRef] [PubMed]

125. Burton, J.L.; McBride, B.W.; Burton, J.H.; Eggert, R.G. Health and reproductive performance of dairy cows treated for up to two consecutive lactations with bovine somatotropin. J. Dairy Sci. 1990, 73, 3258-3265. [CrossRef] [PubMed]

126. Weller, R.F.; Phipps, R.H.; Craven, N.; Peel, C.J. Use of prolonged-release bovine somatotropin for milk production in british friesian dairy cows. 2: Effect on health and reproduction in two consecutive lactations of treatment. J. Agric. Sci. 1990, 115, 105-112.

127. Jordan, D.C.; Aguilar, A.A.; Olson, J.D.; Bailey, C.; Hartnell, G.F.; Madsen, K.S. Effects of recombinant methionyl bovine somatotropin (sometribove) in high producing cows milked three times daily. J. Dairy Sci. 1991, 74, 220-226. [CrossRef] [PubMed]

128. Wells, S.J.; Trent, A.M.; Collier, R.J.; Cole, W.J. Effect of long-term administration of a prolonged release formulation of bovine somatotropin (sometribove) on clinical lameness in dairy cows. Am. J. Vet. Res. 1995, 56, 992-996. [PubMed]

129. Chalupa, W.; Vecchiarelli, B.; Galligan, D.T.; Ferguson, J.D.; Baird, L.S.; Hemken, R.W.; Harmon, R.J.; Soderholm, C.G.; Otterby, D.E.; Annexstad, R.J.; et al. Responses of dairy cows supplemented with somatotropin during weeks 5 through 43 of lactation. J. Dairy Sci. 1996, 79, 800-812.

130. Oldenbroek, J.K.; Garssen, G.J. Effects of treatment of dairy cows with recombinant bovine somatortropin over three or four lactations. J. Dairy Sci. 1993, 76, 453-467. [CrossRef] [PubMed]

131. Zhao Burton, J.H.; McBride, B.W. Lactation, health, and reproduction of dairy cows receiving daily injectable or sustained-release somatotropin. J. Dairy Sci. 1992, 75, 3122-3130. [CrossRef] [PubMed]

132. Elanco Posilac Drug Label. Available online: https://www.elancocentral.com/posilac_label.pdf (accessed on 16 October 2014). 
133. Elvinger, F.; Natzke, R.P.; Hansen, P.J. Interactions of heat stress and bovine somatotropin affecting physiology and immunology of lactating cows. J. Dairy Sci. 1992, 75, 449-462. [CrossRef] [PubMed]

134. Steinfeld, H.; Gerber, P. Livestock production and the global environment: Consume less or produce better? Proc. Natl. Acad. Sci. USA 2010, 107, 18237-18238. [CrossRef] [PubMed]

135. Steinfeld, H.; Gerber, P.; Opio, C. Responses on environmental issues. In Livestock in a Changing Landscape: Drivers, Consequences, and Responses; Steinfeld, H., Mooney, H.A., Schneider, F., Neville, L.E., Eds.; Island Press: Washington, DC, USA, 2010; Volume 1, p. 313.

136. Herrero, M.; Havlík, P.; Valin, H.; Notenbaert, A.; Rufino, M.C.; Thornton, P.K.; Blümmel, M.; Weiss, F.; Grace, D.; Obersteiner, M.; et al. Biomass use, production, feed efficiencies, and greenhouse gas emissions from global livestock systems. Proc. Natl. Acad. Sci. USA 2013, 110, 20888-20893.

137. De Vries, M.; Boer, I.J.M. Comparing environmental impacts for livestock products: A review of lifecycle assessments. Livest. Sci. 2010, 128, 1-11. [CrossRef]

138. FAOSTAT 2012; FAO: Rome, Italy, 2012.

139. Marchant, J.N.; Broom, D.M. Effects of dry sow housing conditions on muscle weight and bone strength. Anim. Sci. 1996, 62, 105-113. [CrossRef]

140. Marchant, J.N.; Rudd, A.R.; Broom, D.M. The effects of housing on heart rate of gestating sows during specific behaviours. Appl. Anim. Behav. Sci. 1997, 55, 67-78. [CrossRef]

141. Barnett, J.L.; Hemsworth, P.H.; Cronin, G.M.; Jongman, E.C.; Hutson, G.D. A review of the welfare issues for sows and piglets in relation to housing. Aust. J. Agric. Res. 2001, 52, 1-28. [CrossRef]

142. Vestergaard, K.; Hansen, L.L. Tethered versus loose sows: Ethological observations and measures of productivity. I. Ethological observations during pregnancy and farrowing. Ann. Rech. Vet. 1984, 15, 245-256.

143. Mason, G.J.; Latham, N.R. Can't stop, won't stop: Is stereotypy a reliable animal welfare indicator? Anim. Welf. 2004, 13, S57-S69.

144. Ramonet, Y.; Meunier-Salaun, M.C.; Dourmad, J.Y. High-fiber diets in pregnant sows: Digestive utilization and effects on the behavior of the animals. J. Anim. Sci. 1999, 77, 591-599. [PubMed]

145. Bergeron, R.; Bolduc, J.; Ramonet, Y.; Meunier-Salaun, M.C.; Robert, S. Feeding motivation and stereotypies in pregnant sows fed increasing levels of fibre and/or food. Appl. Anim. Behav. Sci. 2000, 70, 27-40. [CrossRef] [PubMed]

146. Brouns, F.; Edwards, S.A.; English, P.R. Effect of dietary fibre and feeding system on activity and oral behaviour of group housed gilts. Appl. Anim. Behav. Sci. 1994, 39, 215-223. [CrossRef]

147. Robert, S.; Bergeron, R.; Farmer, C.; Meunier-Salaun, M.C. Does the number of daily meals affect feeding motivation and behaviour of gilts fed high-fibre diets? Appl. Anim. Behav. Sci. 2002, 76, 105-117. [CrossRef]

148. Ramonet, Y.; Robert, S.; Aumaitre, A.; Dourmad, J.Y.; Meunier-Salaun, M.C. Influence of the nature of dietary fibre on digestive utilization, some metabolite and hormone profiles and the behaviour of pregnant sows. Anim. Sci. 2000, 70, 275-286. 
149. Holt, J.P.; Johnston, L.J.; Baidoo, S.K.; Shurson, G.C. Effects of a high-fiber diet and frequent feeding on behavior, reproductive performance, and nutrient digestibility in gestating sows. J. Anim. Sci. 2006, 84, 946-955. [PubMed]

150. Mendl, M.T. The Effects of Alternative Forms of Intensive Pig Husbandry on Measures of Pig Welfare. In Proceedings of the First Association of Veterinary Students Animal Welfare Symposium, Cambridge, UK, 1991; Bradley, A., Sckofield, W.L., Eds.; Association of Veterinary Students: Cambridge, UK, 1991.

151. Broom, D.M.; Johnson, K.G. Stress and Animal Welfare; Chapman \& Hall: London, UK, 1993.

152. Kilbride, A.L.; Gillman, C.E.; Green, L.E. Prevalence of foot lesions, limb lesions and abnormal locomotion in pigs on commercial farms in Britain and risks associated with flooring. Pig J. 2008, $61,62-68$.

153. Van Rooijen, J. Operant preference tests with pigs. Appl. Anim. Ethol. 1982, 9, 87-88. [CrossRef]

154. Beattie, V.E.; Walker, N.; Sneddon, I.A. Preference testing of substrates by growing pigs. Anim. Welf. 1998, 7, 27-34.

155. Gonyou, H.W. Group housing of sows: The potential for the future. In Proceedings of the Focus on the Future Conference, Red Deer, AB, Canada, 20-21 February 2001.

156. Philippe, F.; Laitat, M.; Wavreille, J.; Bartiaux-Thill, N.; Nicks, B.; Cabaraux, J. Ammonia and greenhouse gas emission from group-housed gestating sows depends on floor type. Agric. Ecosyst. Environ. 2011, 140, 498-505. [CrossRef]

157. McGlone, J.; Pond, W. Pig Production: Biological Principles and Applications; Delmar Learning: Clifton Park, NY, USA, 2003.

158. Hoffmann, I.; Ajmone-Marsan, P.; Colli, L. Climate change and the characterization, breeding and conservation of animal genetic resources. Anim. Genet. 2010, 41, 32-46. [CrossRef] [PubMed]

159. Gerber, P.; Vellinga, T.; Opio, C.; Steinfeld, H. Productivity gains and greenhouse gas emissions intensity in dairy systems. Livest. Sci. 2011, 139, 100-108. [CrossRef]

160. Garnett, T.; Appleby, M.C.; Balmford, A.; Bateman, I.J.; Benton, T.G.; Bloomer, P.; Burlingame, B.; Dawkins, M.; Dolan, L.; Fraser, D.; et al. Sustainable intensification in agriculture: Premises and policies. Science 2013, 341, 33-34.

161. Pym, R.A.E.; Guerne Bleich, E.; Hoffmann, I. The Relative Contribution of Indigenous Chicken Breeds to Poultry Meat and Egg Production and Consumption in the Developing Countries of Africa and Asia. In Proceedings of the XII European Poultry Conference, EPC, Verona, Italy, 10-14 September 2006.

162. Besbes, B.; Thieme, O.; Rota, A.; Guéye, E.F.; Alders, R.G. Technology and programmes for sustainable improvement of village poultry production. In Alternative Systems for Poultry: Health, Welfare and Productivity; Poultry Science Symposium Series; Sandilands, V., Hocking, P.M., Eds.; CAB International: Wallingford, UK, 2012; Volume 30, pp. 110-127.

163. Rushen, J.; de Passillé, A.M. The Importance of Improving Cow Longevity. In Proceedings of the Cow Longevity Conference, Tumba, Sweden, 28-29 August 2013; DeLaval International AB: Hamra Farm/Tumba, Sweden, 2013; pp. 3-21. 
164. Evans, R.D.; Wallace, M.; Shalloo, L.; Garrick, D.J.; Dillon, P. Financial implications of recent declines in reproduction and survival of Holstein-friesian cows in spring-calving Irish dairy herds. Agric. Syst. 2006, 89, 165-183. [CrossRef]

165. Garnsworthy, P.C. The environmental impact of fertility in dairy cows: A modelling approach to predict methane and ammonia emissions. Anim. Feed Sci. Tech. 2004, 112, 211-223. [CrossRef]

166. Monteny, G.-J.; Bannink, A.; Chadwick, D. Greenhouse gas abatement strategies for animal husbandry. Agric. Ecosyst. Environ. 2006, 112, 163-170. [CrossRef]

167. Wall, E.; Bell, M.J.; Simm, G. Developing breeding schemes to assist mitigation. In Proceedings of the Livestock and Global Climate Change Conference, Hammamet, Tunisia, 17-20 May 2008; Rowlinson, P., Steele, M., Nefzaoui, A., Eds.; Cambridge University Press: Hammamet, Tunisia, 2008; pp. 44-47.

168. Rogers, G.W.; Banos, G.; Sander-Nielsen, U. Genetic correlations among protein yield, productive live, and type traits from the united states and disease other than mastitis from denmark and sweden. J. Dairy Sci. 1999, 82, 1331-1338. [CrossRef] [PubMed]

169. Wathes, C.M.; Kristensen, H.H.; Aerts, J.-M.; Berckmans, D. Is precision livestock farming an engineer's daydream or nightmare, an animal's friend or foe, and a farmer's panacea or pitfall? Comput. Electron. Agric. 2008, 64, 2-10. [CrossRef]

170. Berckmans, D. Automatic On-line Monitoring of Animals by Precision Livestock Farming. In Proceedings of International Society for Animal Hygiène, Saint-Malo, France, 11-13 October 2004; pp. 27-30.

171. Chedad, A.; Moshou, D.; Aerts, J.M.; van Hirtum, A.; Ramon, H.; Berckmans, D. Recognition system for pig cough based on probabilistic neural networks. J. Agric. Eng. Res. 2001, 79, 449-457. [CrossRef]

172. Tothill, J.C. The Role of Legumes in Farming Systems of Sub-Saharan Africa. Potentials of Forage Legumes in Farming Systems of Sub-Saharan Africa. In Proceedings of a Workshop Held at ILCA, Addis Ababa, Ethiopia, 16-19 September 1985; Haque, I., Jutzi, S., Neate, P.J.H., Eds.; ILCA: Addis Ababa, Ethiopia, 1985.

173. Conant, R.T.; Paustian, K.; Elliott, E.T. Grassland management and conversion into grassland: Effects on soil carbon. Ecol. Appl. 2001, 11, 343-355. [CrossRef]

174. Liebig, M.A.; Hendrickson, J.R.; Berdahl, J.D. Response of soil carbon and nitrogen to transplanted alfalfa in North Dakota rangeland. Can. J. Soil Sci. 2010, 90, 523-526. [CrossRef]

175. Mortenson, M.C.; Schuman, G.E.; Ingram, L.J. Carbon sequestration in rangelands interseeded with yellow-flowering alfalfa (Medicago sativa ssp. Falcata). Environ. Manag. 2004, 33, S475-S481.

176. Benchaar, C.; Pomar, C.; Chiquette, J. Evaluation of dietary strategies to reduce methane production in ruminants: A modelling approach. Can. J. Anim. Sci. 2001, 81, 563-574. [CrossRef]

177. Waghorn, G.C.; Tavendale, M.H.; Woodfield, D.R. Mathanogenesis from forages fed to sheep. Proc. N. Z. Grassl. Assoc. 2002, 64, 167-171.

178. McCaughey, W.P.; Wittenberg, K.; Corrigan, D. Impact of pasture type on methane production by lactating beef cows. Can. J. Anim. Sci. 1999, 79, 221-226. [CrossRef] 
179. Lee, J.M.; Woodward, S.L.; Waghorn, G.C.; Clark, D.A. Methane emissions by dairy cows fed increasing proportions of white clover (Trifolium repens) in pasture. Proc. N. Z. Grassl. Assoc. 2004, 66, 151-155.

180. Barry, T.N.; McNabb, W.C. The implications of condensed tannins on the nutritive value of temperate forages fed to ruminants. Br. J. Nutr. 1999, 81, 263-272. [PubMed]

181. Hammond, K.J.; Hoskin, S.O.; Burke, J.L.; Waghorn, G.C.; Koolaard, J.P.; Muetzel, S. Effects of feeding fresh white clover (Trifolium repens) or perennial ryegrass (Lolium perenne) on enteric methane emissions from sheep. Anim. Feed Sci. Technol. 2011, 166-167, 398-404.

182. Edmondson, M.A.; Roberts, J.F.; Baird, A.N.; Bychawski, S.; Pugh, D.G. Theriogenology of sheep and goats. In Sheep and Goat Medicine, 2nd ed.; Pugh, D.G., Baird, A.N., Eds.; Elsevier: Maryland Heights, MO, USA, 2012; pp. 198 and p. 202198 and p. 202.

183. D'Mello, J.P.F. Chemical constraints to the use of tropical legumes in animal nutrition. Anim. Feed Sci. Technol. 1992, 38, 237-261. [CrossRef]

184. Martin, C.; Morgavi, D.P.; Doreau, M. Methane mitigation in ruminants: From microbe to the farm scale. Animal 2010, 4, 351-365. [CrossRef] [PubMed]

185. Jordan, E.; Lovett, D.K.; Hawkins, M.; Callan, J.; O’Mara, F.P. The effect of varying levels of coconut oil on intake, digestibility and methane output from continental cross beef heifers. Anim. Sci. 2006, 82, 859-865. [CrossRef]

186. Machmüller, A.; Ossowski, D.A.; Kreuzer, M. Comparative evaluation of the effects of coconut oil, oilseeds and crystalline fat on methane release, digestion and energy balance in lambs. Anim. Feed Sci. Technol. 2000, 85, 41-60. [CrossRef]

187. DeRamus, H.A.; Clement, T.C.; Giampola, D.D.; Dickison, P.C. Methane emissions of beef cattle on forages: Efficiency of grazing management systems. J. Environ. Qual. 2003, 32, 269-277. [CrossRef] [PubMed]

188. Beauchemin, K.A.; Colombatto, D.; Morgavi, D.P.; Yang, W.Z. Use of exogenous fibrolytic enzymes to improve feed utilization by ruminants. J. Anim. Sci. 2003, 81, E37-E47.

189. Chaucheyras, F.; Fonty, G.; Bertin, G.; Gouet, P. In vitro utilization by a ruminal acetogenic bacterium cultivated alone or in association with an archaea methanogen is stimulated by a probiotic strain of saccharomyces cerevisiae. Appl. Environ. Microbiol. 1995, 61, 3466-3467.

190. Dourmad, J.Y.; Jondreville, C. Impact of nutrition on nitrogen, phosphorus, $\mathrm{Cu}$ and $\mathrm{Zn}$ in pig manure, and on emissions of ammonia and odours. Livest. Sci. 2007, 112, 192-198. [CrossRef]

191. Moraes, L.E.; Fadel, J.G. Minimizing environmental impacts of livestock production using diet optimization models. In Sustainable Animal Agriculture; Kebreab, E., Ed.; CABI: Wallingford, UK, 2013; pp. 67-82.

192. Lemaire, G.; Franzluebbers, A.; Carvalho, P.C.D.F.; Dedieu, B. Integrated crop-livestock systems: Strategies to achieve synergy between agricultural production and environmental quality. Agric. Ecosyst. Environ. 2014, 190, 4-8. [CrossRef]

193. Franzluebbers, A.J.; Stuedemann, J.A. Surface soil changes during twelve years of pasture management in the Southern Piedmont USA. Soil Sci. Soc. Am. J. 2010. [CrossRef]

194. Soussana, J.F; Tallec, T.; Blanfort, V. Mitigating the greenhouse gas balance of ruminant production systems through carbon sequestration in grasslands. Animal 2010, 4, 334-350. 
195. Cox, S. Perennial Crops for Food Security. In Proceedings of the FAO Expert Workshop, Rome, Italy, 28-30 August 2013; Batello, C., Wade, L., Cox, S., Pogna, N., Bozzini, A., Choptiany, J., Eds.; Food and Agriculture Organization of the United Nations: Rome, Italy, 2013.

196. Lal, R. Soil carbon sequestration to mitigate climate change. Geoderma 2004, 123, 1-22. [CrossRef]

197. Smith, P.; Martino, D.; Cai, Z.; Gwary, D.; Janzen, H.; Kumar, P.; McCarl, B.; Ogle, S.; O’Mara, F.; Rice, C.; et al. Agriculture. In Climate Change 2007: Mitigation of Climate Change. Contribution of Working Group III to the Fourth Assessment Report of the Intergovernmental Panel on Climate Change; Metz, B., Davidson, O.R., Bosch, P.R., Dave, R., Meyer, L.A., Eds.; Cambridge University Press: Cambridge, UK; New York, NY, USA, 2007; pp. 498-540.

198. Thornton, P.K.; Herrero, M. Potential for reduced methane and carbon dioxide emissions from livestock and pasture management in the tropics. Proc. Natl. Acad. Sci. USA 2010, 107, 19667-19672. [CrossRef] [PubMed]

199. Owen, E.; Smith, T.; Makkar, H. Successes and failures with animal nutrition practices and technologies in developing countries: A synthesis of an FAO e-conference. Anim. Feed Sci. Technol. 2012, 174, 211-226. [CrossRef]

200. Smil, V. Worldwide transformation of diets, burdens of meat production and opportunities for novel food proteins. Enzym. Microb. Technol. 2002, 30, 305-311. [CrossRef]

201. Cao, Y.; Li, D. Impact of increased demand for animal protein products in Asian countries: Implications on global food security. Anim. Front. 2013, 3, 48-55. [CrossRef]

202. OECD-FAO Agricultural Outlook 2013-2022. Available online: http://www.oecd.org/site/oecdfaoagriculturaloutlook/summary-2013-EN.pdf (accessed on 13 May 2015).

203. Pelletier, N.; Tyedmers, P. Forecasting potential global environmental costs of livestock production 2000-2050. Proc. Natl. Acad. Sci. USA 2010, 107, 18371-18374. [CrossRef] [PubMed]

204. Garnett, T. Livestock-related greenhouse gas emissions: Impacts and options for policy makers. Environ. Sci. Policy 2009, 491-503. [CrossRef]

205. Strid Eriksson, I.; Elmquist, H.; Nybrant, T. Environmental system analysis of pig production. Int. J. Life Cycle Assess. 2005, 10, 143-154. [CrossRef]

206. Pelletier, N.; Ibarburu, M.; Xin, H. A carbon footprint analysis of egg production and processing supply chains in the Midwestern United States. J. Clean. Prod. 2013, 54, 108-114. [CrossRef]

207. Garnett, T. Where are the best opportunities for reducing greenhouse gas emissions in the food system (including the food chain)? Food Policy 2011, 36, S23-S32. [CrossRef]

208. Parfitt, J.; Barthel, M.; Macnaughton, S. Food waste within food supply chains: Quantification and potential for change to 2050. Philos. Trans. R. Soc. Lond. Ser. B Biol. Sci. 2010, 365, 3065-3081. [CrossRef]

209. Gustavsson, J.; Cederberg, C.; Sonesson, U.; van Otterdijk, R.; Meybeck, A. Global Food Losses and Food Waste; FAO: Rome, Italy, 2011.

210. Smith, P.; Haberl, H.; Popp, A.; Erb, K.H.; Lauk, C.; Harper, R.; Tubiello, F.N.; de Siqueira Pinto, A.; Jafari, M.; Sohi, S.; et al. How much land-based greenhouse gas mitigation can be achieved without compromising food security and environmental goals? Glob. Chang. Biol. 2013, 19, 2285-2302. 
211. Carlsson-Kanyama, A.; Ekstrom, M.P.; Shanahan, H. Food and life cycle energy inputs: Consequences of diet and ways to increase efficiency. Ecol. Econ. 2003, 44, 293-307. [CrossRef]

212. Berners-Lee, M.; Hoolohan, C.; Cammack, H.; Hewitt, C.N. The relative greenhouse gas impacts of realistic dietary choices. Energy Policy 2012, 43, 184-190. [CrossRef]

213. Soret, S.; Mejia, A.; Batech, M.; Jaceldo-Siegl, K.; Harwatt, H.; Sabate, J. Climate change mitigation and health effects of varied dietary patterns in real-life settings throughout North America. Am. J. Clin. Nutr. 2014, 100, 490S-495S. [CrossRef] [PubMed]

214. Scarborough, P.; Appleby, P.N.; Mizdrak, A.; Briggs, A.D.M.; Travis, R.C.; Bradbury, K.E.; Key, T.J. Dietary greenhouse gas emissions of meat-eaters, fish-eaters, vegetarians and vegans in the UK. Clim. Chang. 2014, 125, 179-192. [CrossRef]

215. Stehfest, E.; Bouwman, L.; van Vuuren, D.P.; den Elzen, M.G.J.; Eickhout, B.; Kabat, P. Climate benefits of changing diet. Clim. Chang. 2009, 95, 83-102. [CrossRef]

216. Mekonnen, M.M.; Hoekstra, A.Y. A global assessment of the water footprint of farm animal products. Ecosystems 2012, 15, 401-415. [CrossRef]

217. Reijnders, L.; Soret, S. Quantification of the environmental impact of different dietary protein choices. Am. J. Clin. Nutr. 2003, 78, 664S-668S. [PubMed]

218. McMichael, A.J.; Powles, J.W.; Butler, C.D.; Uauy, R. Food, livestock production, energy, climate change, and health. Lancet 2007, 370, 1253-1263. [CrossRef] [PubMed]

219. Fry, J.; Neff, R. Healthy Monday: Two Literature Reviews; Johns Hopkins School of Public Health: Baltimore, MD, USA, 2010.

220. Tuomisto, H.L.; Teixeira de Mattos, M.J. Environmental impacts of cultured meat production. Environ. Sci. Technol. 2011, 45, 6117-6123. [CrossRef] [PubMed]

221. De Boer, I.J.M.; Cederberg, C.; Eady, S.; Gollnow, S.; Kristensen, T.; Macleod, M.; Meul, M.; Nemecek, T.; Phong, L.T.; Thoma, G.; et al. Greenhouse gas mitigation in animal production: Towards an integrated life cycle sustainability assessment. Curr. Opin. Environ. Sustain. 2011, 3, 423-431.

222. Lammers, P.J.; Honeyman, M.S.; Harmon, J.D.; Helmers, M.J. Energy and carbon inventory of iowa swine production facilities. Agric. Syst. 2010, 103, 551-561. [CrossRef]

223. Leinonen, I.; Williams, A.G.; Kyriazakis, I. The effects of welfare-enhancing system changes on the environmental impacts of broiler and egg production. Poult. Sci. 2014, 93, 256-266. [CrossRef] [PubMed]

224. Haas, G.; Wetterich, F.; Koepke, U. Comparing intensive, extensified and organic grassland farming in Southern Germany by process life cycle assessment. Agric. Ecosyst. Environ. 2001, 83, 43-53. [CrossRef]

225. Hörtenhuber, S.; Lindenthal, T.; Amon, B.; Markut, T.; Kirner, L.; Zollitsch, W. Greenhouse gas emissions from selected austrian dairy production systems-Model calculations considering the effects of land use change. Renew. Agric. Food Syst. 2010, 25, 316-329. [CrossRef]

(C) 2015 by the authors; licensee MDPI, Basel, Switzerland. This article is an open access article distributed under the terms and conditions of the Creative Commons Attribution license (http://creativecommons.org/licenses/by/4.0/). 